\title{
رحلات الصوفية الى الأناضول في عهد سلاجقة الروم
}

$$
\text { أحلام عابد حسين" و فرست مرست مرعي الدهوكي 1300-1300م) }
$$

قسم التاريخ، فاكلتي العلوم الأنسانية، جامعة زاخو، أقليم كوردستان، العراق. (ahlam.barwari72@gmail.com )

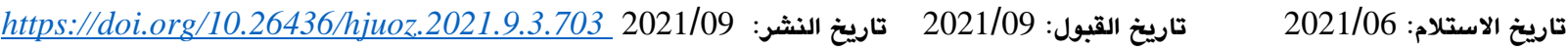

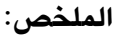

يتناول هذا البحث دراسة رحلات كبار الصوفية الذين وفدوا الى بلاد الأناضول عهد سلاجقة الروم من مختلف مناطق العالم الإسلامي،

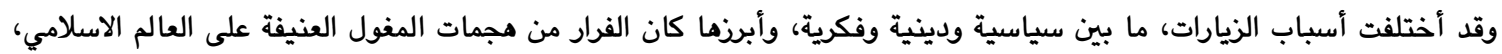

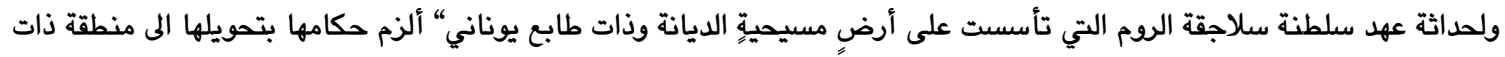
ثقافة اسلامية بإعتبارهم أتباع الخلافة العباسية، فأحتضنوا العلماء ورجال التصوف من خلال توفير ما يؤمن بقائهم، فأصبحت

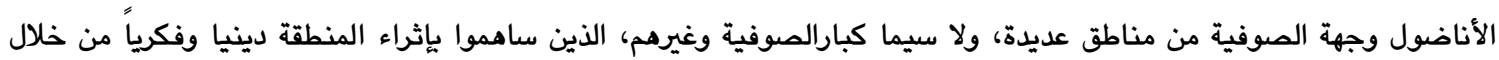

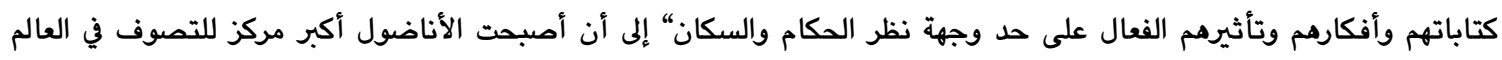
الاسلامي خلال القرنين السادس والسابع الهجريين/الثاني والثالث عشر الميلادين والثين. الكلمات الدالة: الصوفية، الرحلات، سلاجقة الروم، الاناضول، آسيا الصغرى.

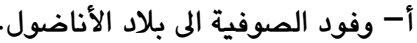

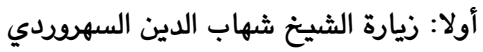
ثانيا: رحلة محي الدين أبن عربي

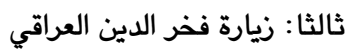
رابعا: زيارة أوحد الدين كرماني خامسا: رحلة جلال الدين الرومي (زيارة برهان الدين محقق الترمذي، وشمس الدين التبريزي). سادسا: زيارة نجم الدين الرازي (دايه). ب- موقف سلاطين سلاجقة الروم من كبار الصوفية. ج- أفكارهم ومؤلفاتهم وتأثيرهم على المجتمع التركماني. من البديهي لكل بحث صعوياته لعل أبرز الصعوبات التي واجهتها الباحثة هي قلة المصادر التي كتبت عن سلاجقة الروم ولا سيما جانبهم الحضاري، ومذه ما الزمت الباحثة للرجوع الى المصادر والمراجع

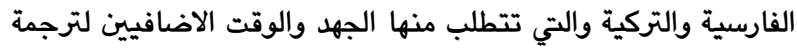
تلك النصوص وإثراء البحث بمعلومات لا غنى عنها.

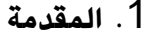

تعد ظاهرة التصوف سمة بارزة في تاريخ سلطنة سلاجقة الروم، فقد حظيت الصوفية بإهتمام كبير لدى الحكام والسلاطين الذين وفروا ما

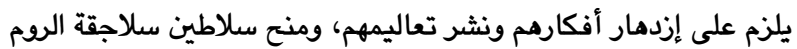
مكانة مرموقة لرجال التصوف مما دفعت الصوفية الهجرة الى السلطنة حتى أصبحت الأناضول وجهة الصوفية من مختلف المناطق خلال سنوات (600-704هـ/1200-1307م) عمل كبار الصوفية بعد استقرارهم في بلاد الأناضول على نشر أفكارهم وإتجاهاتهم الصوفية مما أدى بطبيعة الحال نشوء التيارات الصوفية، فمن هذا المنطلق جاء أختيار البحث لغرض إلقاء الضوء على الصوفية الوافدين الى الأناضول

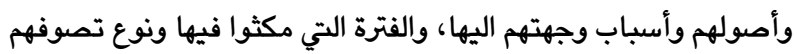

$$
\text { قالمدى البحث المثيرمث على المجتمع التركماني. }
$$

المبحث الثاني: عوامل إنتشار الصوفية في بلاد الأناضول.

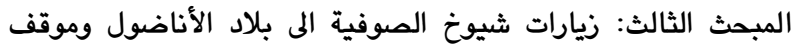

السلطنة منهم. 
ودعوة الانبياء لأ قوامهم إنما كان لعبادة الله، ولقد جاء في الذكر الحكيم

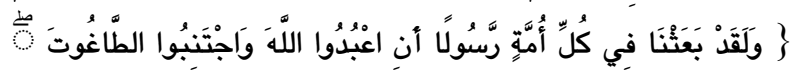

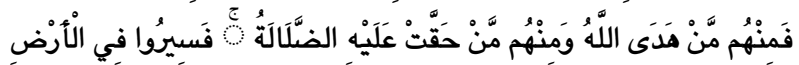

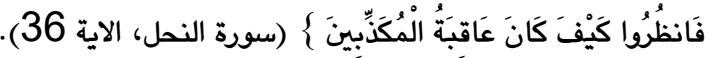
وما تجدر الإثارة اليه هو أن المصطلح الصوفي قد مر بأربعة مراحل: المرحلة الأولى: مرحلة النشأة وغالبا ما كان يدود حول السلوك والاخلاق، كالزهد وترك الملذات الدنيوية، والمرحلة الثانية نشوء مصطلح التصوف الفلسفي الكشفي وظهور الفاظ جديدة مثل الحلول والاتحاد، ووحدة الوجود، ووحدة الشهود، ومن ثم ظهور المصطلح الفلسفي الاثراقي، وفيه طغى النور وتفرعاته على المعاني الصوفية والذي بدأ من القرن الثالث الى القرن السادس، والمرحلة الثالثة وفيها ظهرت المصنفات الجماعية نحو أبدال وما الى ذلك والمرحلة الرابعة استحداث مصطلحات تتعلق بالطرق الصوفية، وزيادة التعريفات المعتمدة على النقل بحسب الطريقة الواحدة نحو أبدال سبعة، إحياء

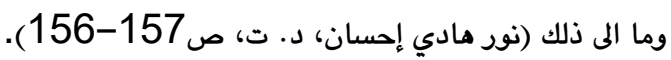

4. المبحث الثاني: عوامل إنتشار التصوف في بلاد الأناضول حدثت في الأناضول تغيرات على عدة أصعدة منها سياسية، ودينية، وقومية، ومذهبية، والتي ادت الى لفت انظار الناس للتصوف حتى بلغ ذروته في الاناضول لدرجة فاقت تصوف الدول الاسلامية القائمة انذاك

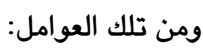
1- تعد الأوضاع السياسية من الاسباب الرئيسية لظهور التصوف في

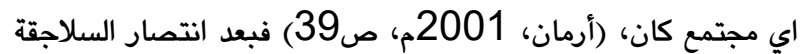
في معركة ملاذكرد سنة (463هـ/1171 م )، فتح المجال للمسلمين الدخول الى الأناضول، ومنهم الصوفية حاملين معهم طرقهم الخاصة

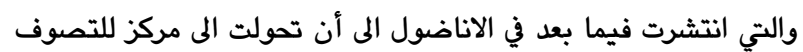

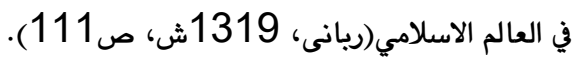

2- بعد تمكن السلاجقة من تثبيت حكمهم في الاناضول، انشأوا العديد من المراكز الدينية، وعينوا الشيوخ فيها ثم اصبح لزاما عليهم استدعاء

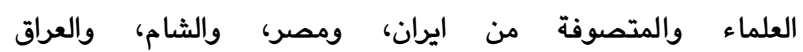
وخراسان(كوبريلى، 1385ش، صنم248). 3- مما سهل مجرة اؤلئك العلماء والمتصوفة هي أن الأناضول واجزاء

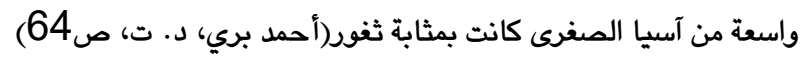

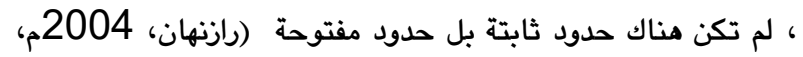

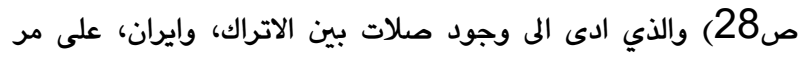
التاريخ الأمر الذي جعل الترك أن يكونوا على صلة وثيقة بأحكام الإسلام وقواعده ، وتمسكهم بالمذهب الحنفي، والحيلولة دون انتشار

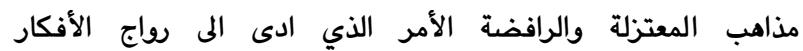

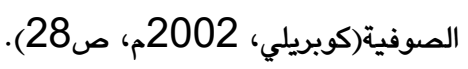

2. تمهيد

كانت الرحلات والسياحة الى مناطق مختلفة ذا أهمية خاصة لدى الصوفية وذلك طلبا للعلوم، فضلا عن نشر الفكر الصوفي ففي القرن السابع الهجري/الثالث عشر الميلادي، أصبحت الأناضول وجهة الصوفية من مختلف المناطق من العراق، وايران، وآسيا الوسطى، بأعتبارها منطقة فيها حرية دينية بسبب التسامح الديني الذي أبداه سلاطين السلاجقة، واكرامهم للعلماء والصوفية الذين حظوا بمكانة مرموقة لدى السلاجقة، فحدث أن توالت على المنطقة زيارات الصوفية منهم من جاء اليها للقيام بمهمة كالسهرودي عندما حمل معه خلعة الفتوة لعدد من سلاطين السلاجقة، فضلا عن منشور الولاية التي كلفها بها الخليفة العباسي الناصر لدين الله، ومنهم من جاء اليها كعادته في الترحال الى عدة مناطق كأبن عربي، وآخرون وفدوا اليها بحثا عن الأمان والاستقرار بعد أن اجتاح المغول مناطق سكناهم مثل نجم الدين داية، وهناك من فرّ بعائلته ولكن بهدف الاستقرار أمثال بهاء الدين ولد والد جلال الدين الرومي، ومنهم من جاء الى الاناضول لوجود هؤلاء الصوفية ولهاء الكبار على سبيل المثال زيارة برهان الدين محقق الترمذي لبهاء الدين ولد ويحثه عنه ومن ثم حمل على عاتقه تعليم ابنه جلال الدين الرومي بما اكتسب من علوم من والده، وآخر من جاء للبحث عن نصفه الثاني كثمس الدين التبريزي ويحثه عن الرومي، وآخرون ممن سنذكرمم خلال

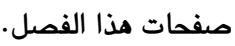

\section{3. المبحث الأول: مفهوم التصوف وتفرعاته}

لا يشكل تعريف مفهوم التصوف ذو أهمية كبيرة لكثرة ما كتب عنه، ولكن يجدر بالدراسة إعطاء صورة مجملة عن الآراء التي قيلت عن أصل مفهوم التصوف، "لان الكلام في الشيء فرع تصور ماهيته وفائدته ومادته بشعور ذهني مكتسب او بديهي ليرجع اليه في افراد ما وقع عليه

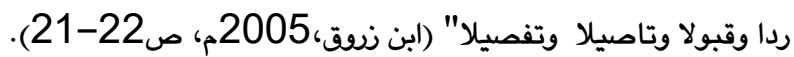
لمصطلح التصوف كثير من التعريفات قد وضعها أئمة التصوف الاوائل كالجنيد ( المتوفي 297هـ/909م ) إمام الطائفة أنه قال: "مذهبنا

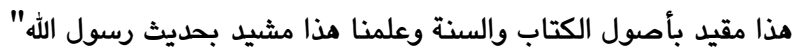

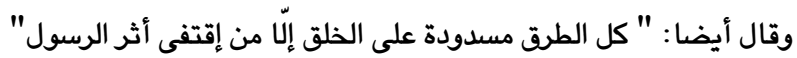

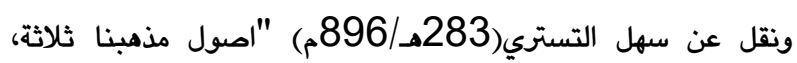
الاقتداء بالنبي في الاخلاق والافعال والاكل من الحلال وإخلاص النية في

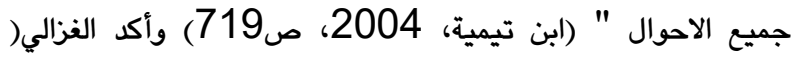
المتوفي سنة505هـ/1111م ) أن كل معاني التصوف موجودة في

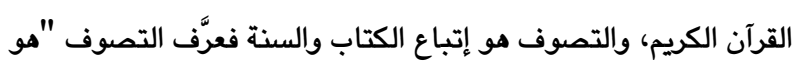
طرح النفس في العبودية و تعلق القلب بالريوبية فإن تصفية القلب عن ولن إن مرافقة البرية و مفارقة الاخلاق الطبيعية، وإخماد الصفات البشرية، ومجانبة الدواعي النفسانية، ومنازلة الصفات الروحانية، والتعلق بالعلوم

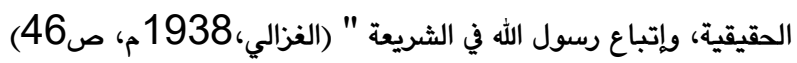


د. ت، ص373) نسبه يتصل بالخليفة الاول أبي بكر الصديق (التادفي،

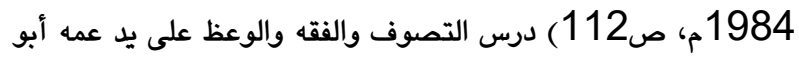
النجيب السهرودي والشيخ أبي محمد محي الدين عبد القادر الجيلاني (ابن الفوطي، 1997م، ص103 103) وتعلم منه الرياضات والمجاهدات

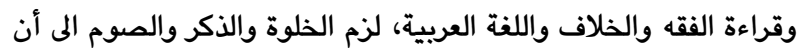
أصبح بإستطاعته الظهور للناس ووعظهم فجلس في مدرسة عمه للوعظ

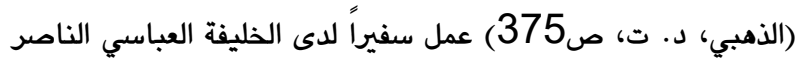

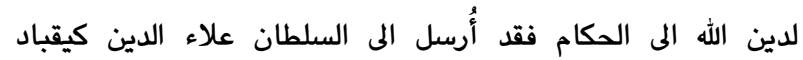

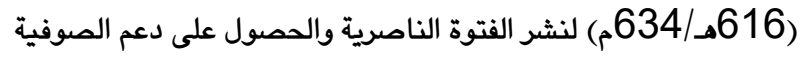

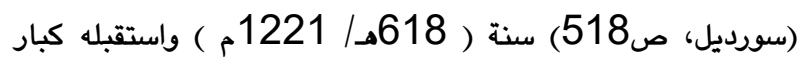
رجال الدولة من القضاة والائمة والمشايخ والمتصوفة والأعيان

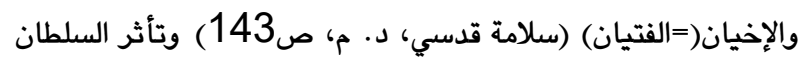
بروحانية الشيخ ودعاه الى قصر السلطنة وفيها خلع عليه خلع الخليفة مدانة من كسوة وعمامة ونعل مذهب، ومن مظاهر الاحتفال بالشيخ أقام له له السلطان مجلس سماع1، في بلاطه وقدم الحاضرين الخدمة اللائقة

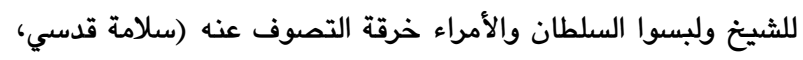
د. ت، ص144) لاسيما السلطان والامراء وهذا ما يوضح أمرين

مهمين:

الاول أن الشيخ السهرودي لم يخلف مجلسا للسماع وهو الذي عرف

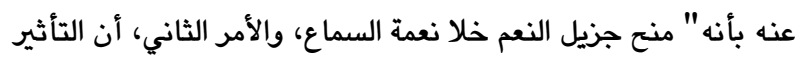
الذي صاحب شخصية الشيخ فاق الهدف الرسمي في زيارته للاناضول

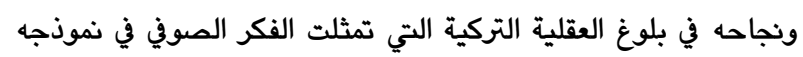

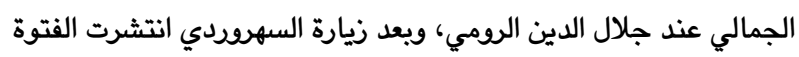
الناصرية في معظم مدن الاناضول والسبب يمكن ارجاعه للمهارات

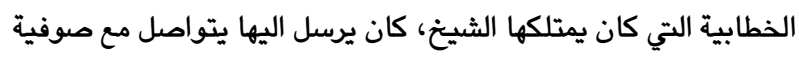

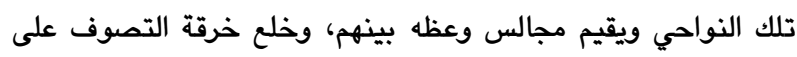

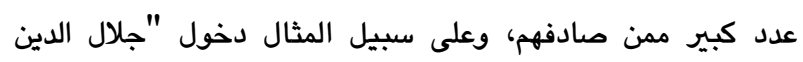

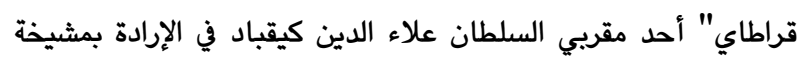

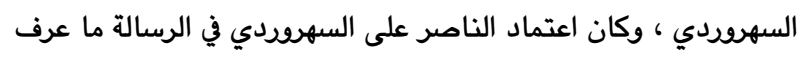

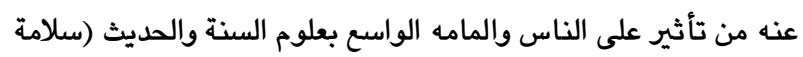

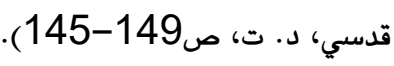
ثانياً: زيارة محي الدين ابن عربي صدي

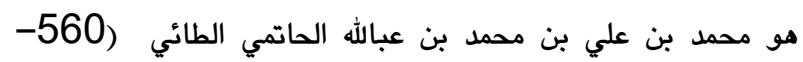

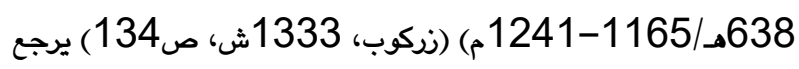
نسبه الى الصحابي الجليل عدي بن حاتم الطائي، عرف بأبن عربي بدون

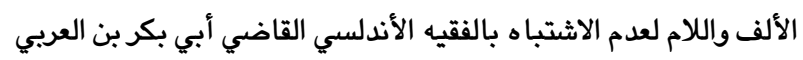
(الزين، 1985م، ص445) ولد في مرسية جنوب الاندلس من عائلة

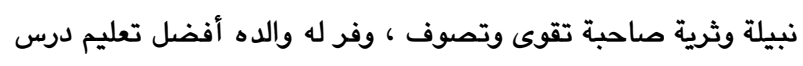

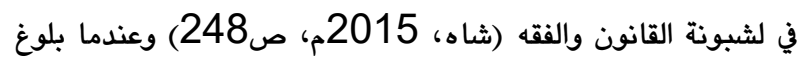

4- وما سهل على المتصوفة في هجراتهم الى الأناضول إعتمادهم على ادلاء الطرق الذين كانوا دائمي الترحال بين المناطق الددودية (رازنهان، 20042م، ص28). 5- اضطلع حكام السلاجقة بإظهار التسامح بشأن الديانات، والمذاهب، ونبذوا التعصب، وآثروا العفو عن كل ما يتصل بالشؤون الدينية، والتيارات المذهبية التي انتشرت في الاناضول muammer ) .Gul, 2005, S194) 6 - وجود بعض الأفكار الغير متجانسة، كانتشار الدين الإسلامي في

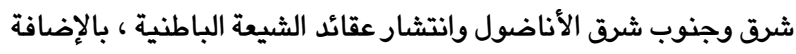

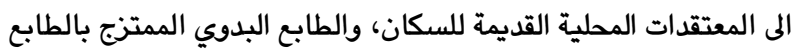

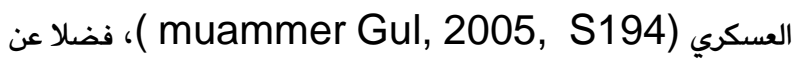
العقائد الباطنية التي كانت منتشرة في العالم الإسلامي خاصة في الشام

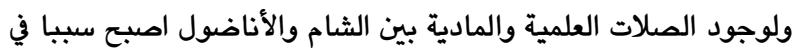

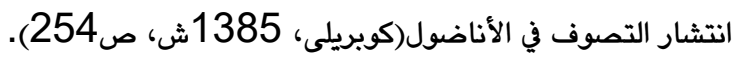

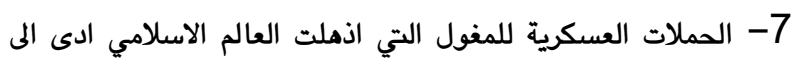

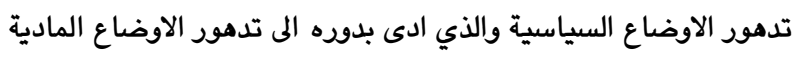

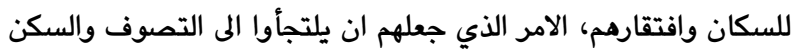
في الخانقاوات، لاسيما الإيرادات المالية للخوانق كانت جيدة، ويسهل العيش فيها لتوفر جميع لوازم الحياة مما ادى بالناس الإننواء فيها

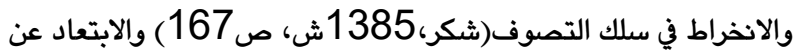
الفتن واعتقدوا ان ذلك احدى الطرق لصد مجمات المغول(رازنهان،

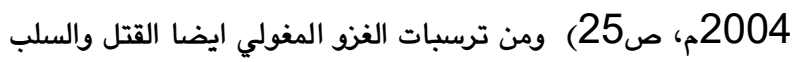
والسرقة وانعدام الامان وكثرة الوساطات، فضلا عن ضعف المبادئ العقائدية والمذهبية عندهم ادى الى استياء الناس من تسلطهم فلم ييقى لهم مأمن سوى التصوف حيث وجدوا فيها راحة نفسية تعينهم في

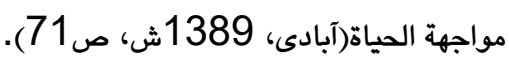

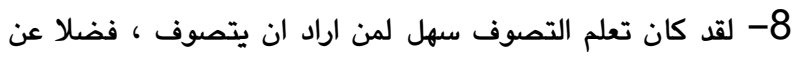
الصوفية انفسهم كانوا اشخاص مسالمين لم يكن لديهم غير العبادة يتوددون للناس وييسطون لهم تعاليم الدين من خلال اخلاقهم واذواقهم

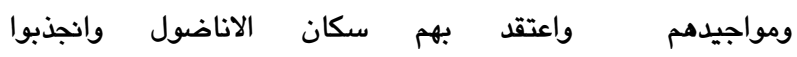
اليهم(شكر،1385ش، صومب156).

4. المبحث الثالث: زيارات شيوخ الصوفية الى بلاد الأناضول وموقف السلطنة منهم. أ- وفود الصوفية الى بلاد الأناضول. اولاً: زيارة شهاب الدين السهرودردي الهوني

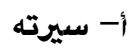
هو أبو حفص ويكنى أيضا بأبي عبدالله بن عمر بن عبدالله بن عمويه

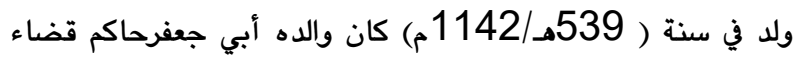

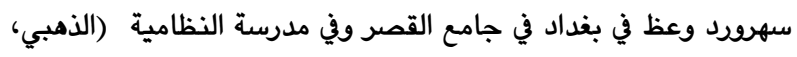


بالشيخ العراقي وكان يطلب منه عقد مجالس السماع ويبقى معه أحيانا

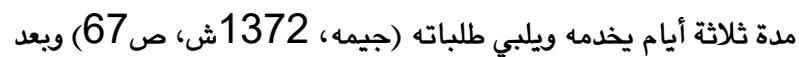

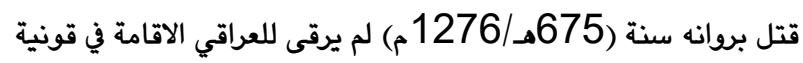
فرحل الى مصر، وهناك عقد مجلسا من كبار الشيوخ لاعطائه لقب

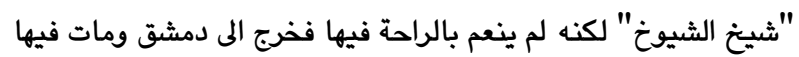

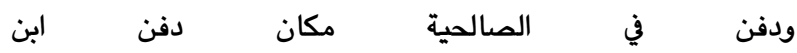

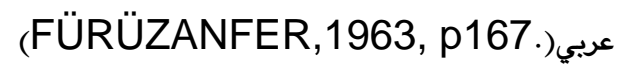
رابعا: زيارة أوحد الدين كرماني

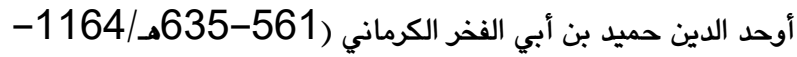

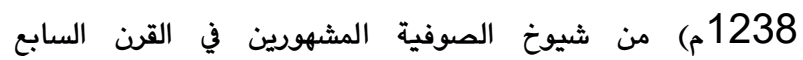
الهجري/الثالث عشر الميلادي، عرف عنه بكثرة سفره (نفيسى،

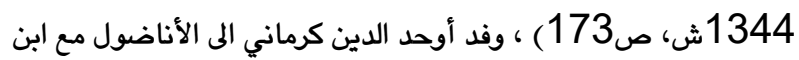

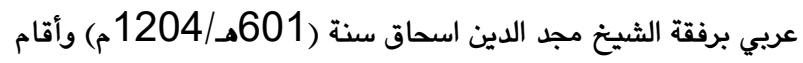
في الأناضول مدة ثلاثون سنة أخذ على عاتقه اصلاح المؤسسات الدينية عن طريق نشر الفتوة الناصرية في الاناضول والتي كانت لتلك الطائفة

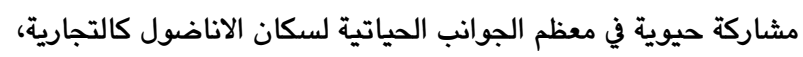

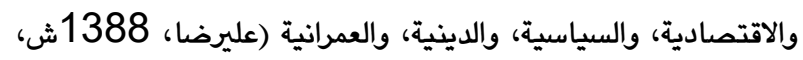

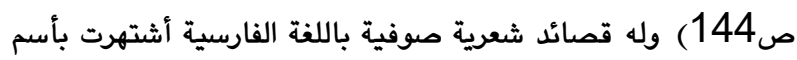

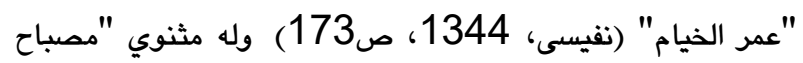
الأرواح" وعدت أفضل القصائد الشعرية في ايران ولفيس، وله أيضا

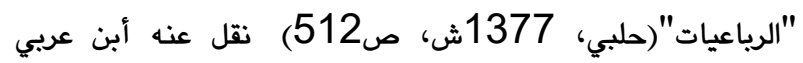

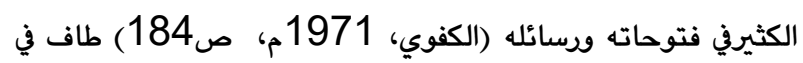
العديد من مدن الأناضول جمعت بينه وبين أبن عربي علاقة صداقة واتة وأحيانا كانا يجتمعان معا في مكان واحد في دمشق أو في مصر وكاهلاهما

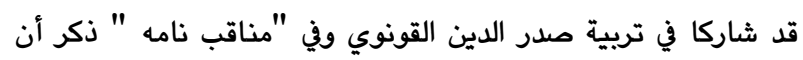

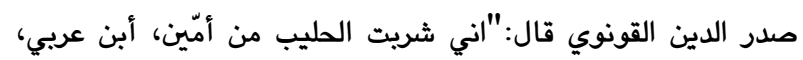

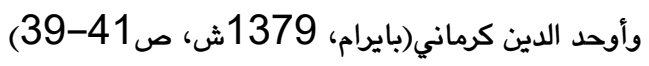

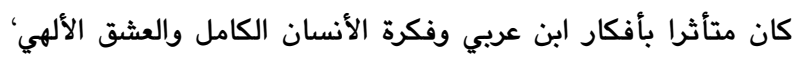

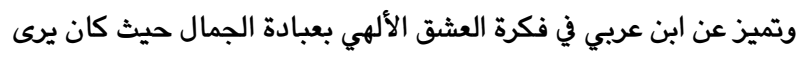

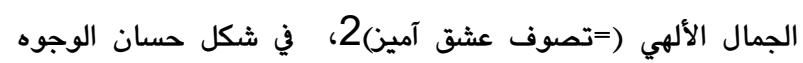

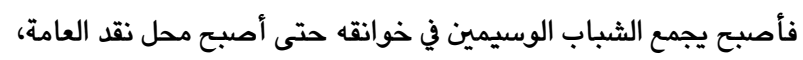

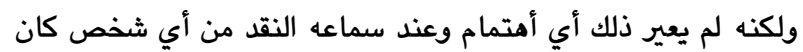

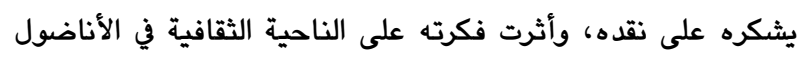

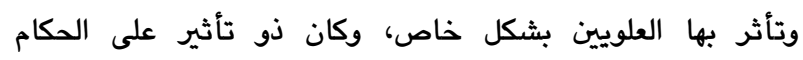
والسلاطين، والعامة لا سيما التركمان سكان القرى والارياف البسطاء

$$
\text { (دزفولى، 1389ش، ص6969). }
$$

خامسا : جلال الدين الرومي أ- أ- سيرته

جلال الدين محمد بن محمد بن الحسين بن أحمد ولد سنة

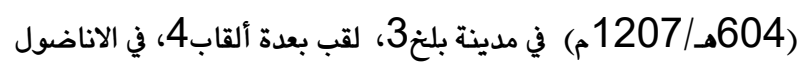

عمره الثامنة (568هـ/1172م) رحلت عائلته الى اشبيلية (الشيبي،

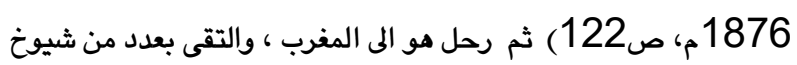

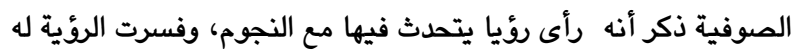

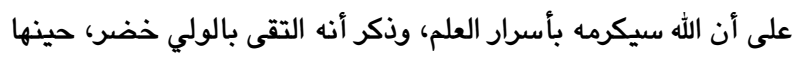

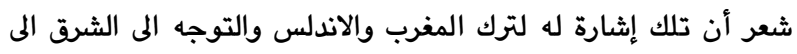
مكة، ومن ثم بغداد، والموصل، وحلب، والقاهرة، والاسكندرية، وقونية،

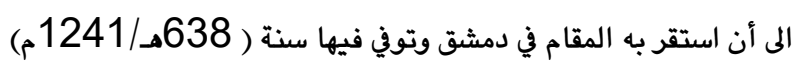

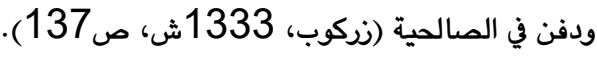

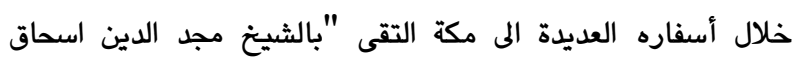

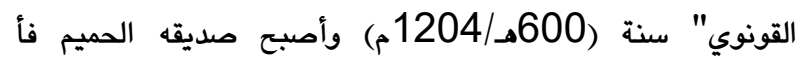

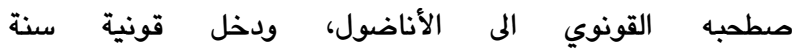
(607هـ/1210م) وأصبح محل تكريم وتبجيل من قبل السلطان

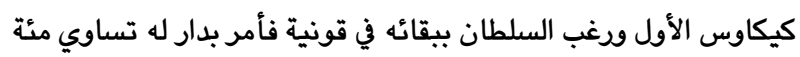

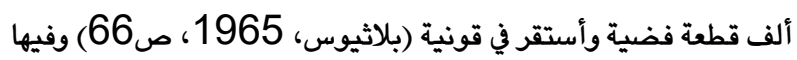

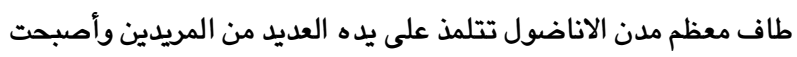
مؤلفاته تدرس في مدارس قونية وترك كتبه وقفا للمكتبة التي أسسها

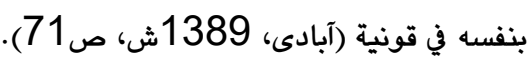
ثالثا : زيارة فخر الدين العراقي

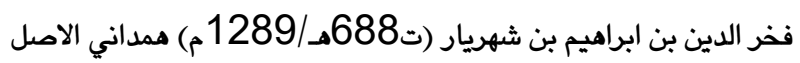

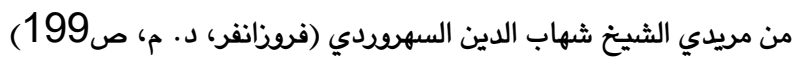

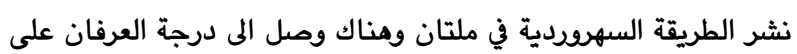
يد الشيخ زكريا الملتاني (ت633هـ/1235م) بعد وفاة مرشده ذهب الطبان

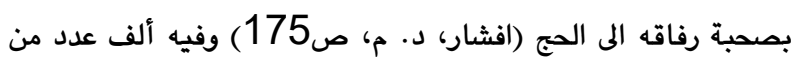

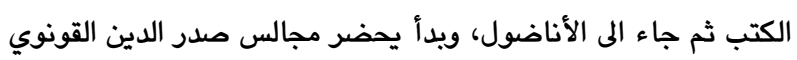
في قونية وأصبح أحد مريديه وعمل في التدريس (أقسرائى،

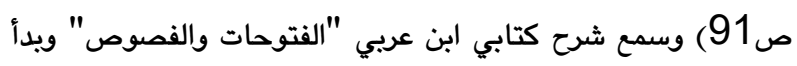

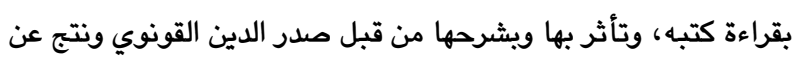

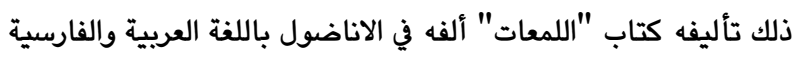

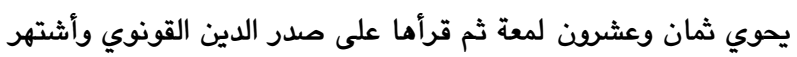

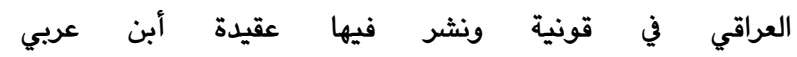

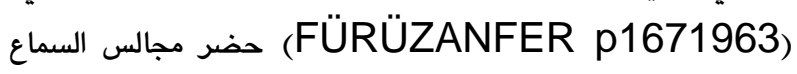
للرومي وتأثر بطريقته ( وتأثر أيضا بالطريقة السهرودية، والكبروية، والأكبرية) (جيمه، 1372ش، صتأنريقه (61-42)، وجمعت بينه وبين

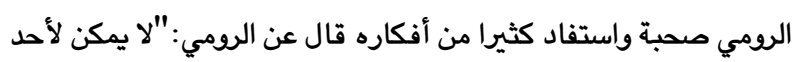

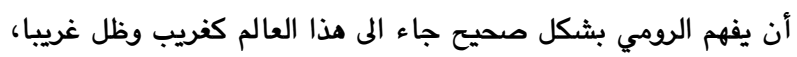
ورحل بغرابة (FÜRÜZANFER,1963, p168)

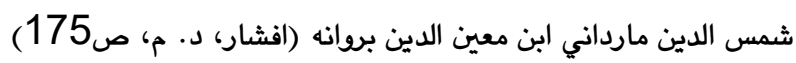

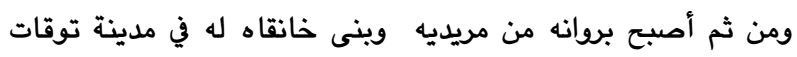

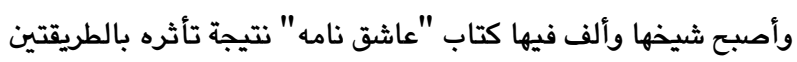
"القونوية، والمولوية" (جيمه، 1372 ش، ص 61-46) تعلق بروانه 
في سنة (629هـ/1223م) جاء الى قونية الشيخ برهان الدين محقق

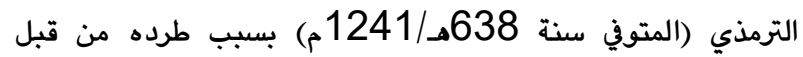
المغول من خراسان فتوجه الى الاناضول لما سمع من كرم السلطان

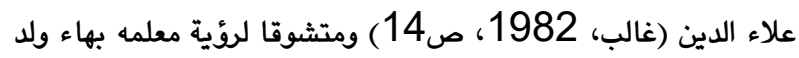

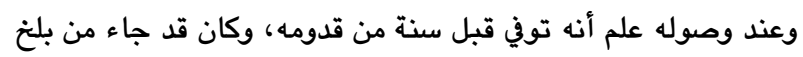

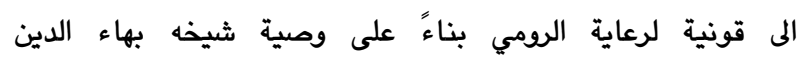

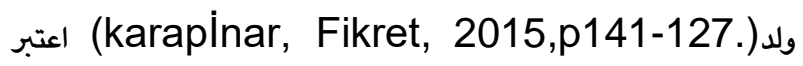
المعلم الثاني للرومي بعد والده وعلمه العلوم اللدنية، والحكمة الملهمة، وأسرار الصياة الصوفية، واعمال نثرية، وزاد عليه الخلوات الاربعينية لبلوغ درجة الكشف الصوفي، وفي النهاية بعثه الى الشام لتلقي العلوم الصوفية ولقاء شيوخ الصوفية المقيمين آنذاك في الشام أمثال محي لي لئهي الدين بن عربي، ودرس على يده العلوم الباطنية التأويلية وصحب تلميذه صدر الدين القونوي، وأوحد الدين كرماني، وغيرهم من مريدي بدهي

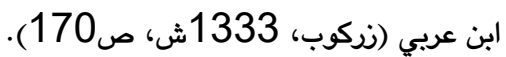
تناقضت الروايات في بعض المصادر حول لقاء جلال الدين الرومي بأبن عربي من عدمه أثناء اقامته في الشام، مع ذكر تأثره بأفكاره ولكن يبدو من سنة عودة الرومي الم قونية (638هـ/1241م) وهي سنة

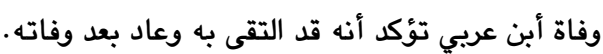

زيارة شمس الدين التبريزى الى قونية وعلاقة الرومي به به به وفيه بعد وفاة برهان الدين الترمذي ظل الرومي يتولى التدريس والوعظ

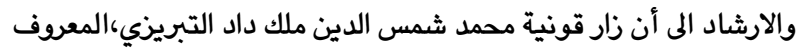

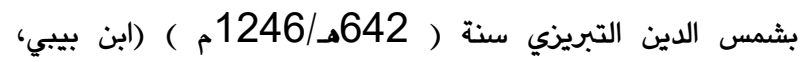
1350ش، ص118) أحد الاقطاب المشهورين في عالم التصوف يرجع نسب والده علاء الدين الى كيا بزرك زعيم الاسماعيلية (غالب،

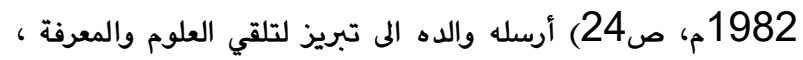

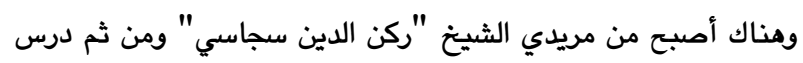
التصوف على يد الشيخ "بابا كمال الجندي" أبي بكر السلال التبريزي

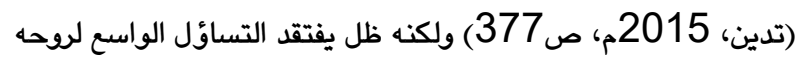
لذلك بحث عن شيخ آخر يشبع تساؤله الروحي حيث أنه قال:" كنت

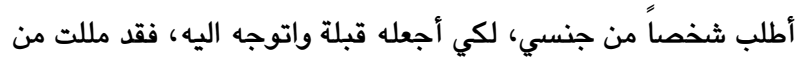
نفسي" (الرومي، د. م، ص1414) وقيل أنه قدم الى بلاد الروم تنفيذاً

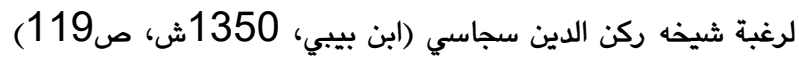
وذكرت شيمل نقلاً عن سبهسالار أن شمس تبريزي رحل الى الاناضول

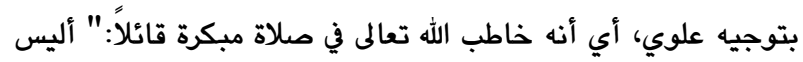

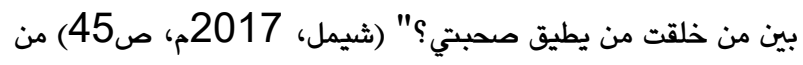

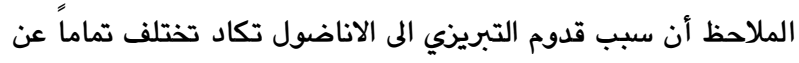
اسباب قدوم الشيوخ السابقين، وقد وصل الى قونية بعد أن أتم المغول

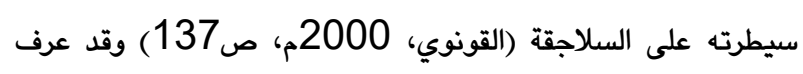
عنه : عارف، فريد، وحيد، متميز في تصرفاته، وأفكاره، وأقواله،

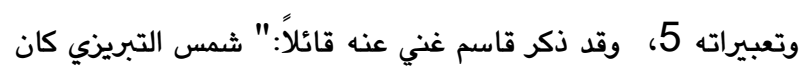

عرف ب"مولانا" بمعنى "خواجه" وفي المصادر الفارسية الحديثة أطلق عليه" مولوي" (الرومي، د. ت، ص111) والده بهاء الدين محمد بن حسين الخطيبي البلخي المعروف ب "بهاء ولد" كان من عائلة ثرية

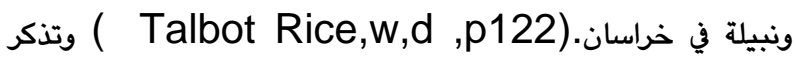
بعض الروايات أن نسبه يصل الى "أبو بكر الصديق" وأمه تصل نسبها

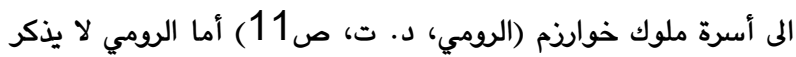
أي معلومات عن نسبه في مؤلفاته وقد ذكر في إحدى رباعياته: "أصلم تركست أكر جه هندي كويم" بمعنى "إني تركي الأصل ولوأني

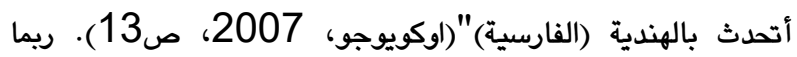
إقامته بين الأتراك دفعته للقول بذلك الأصل.

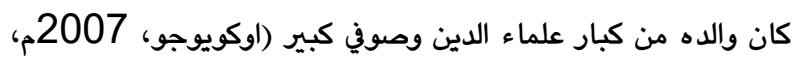
ص12) عندما أقترب خطر المغول على خراسان ترك بلخ، وفي طريقهم

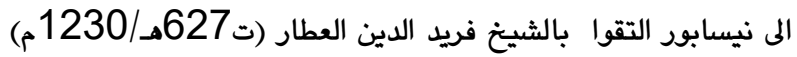
، اعجب الشيخ "العطار" بالشاب الصغير "الرومي" ويذكائه وفطنته واهداه كتابه "اسرار نامه ( =إلهي نامه) وقال لوالده : إن ابنه سيضرم

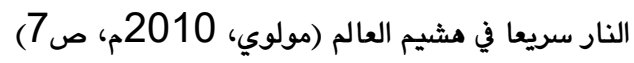
ويمكن اجمال دوافع هجرة بهاء الدين ولد بأسرته وعزمه اللجوء الى الى هولها

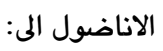

- ذكرت التقاليد الصوفية الى أنه منذ اعتراف الاقطاب الصوفية المعاصرون بالامكانيات الروحية للشاب "الرومي" أصبح اهتمامهم

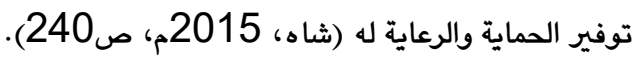
- اضطهاد الصوفيون في بلخ وقد بلغ الاضطهاد الى اغراق أحدهم في

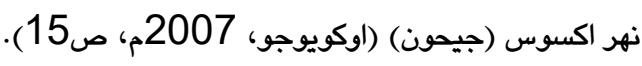

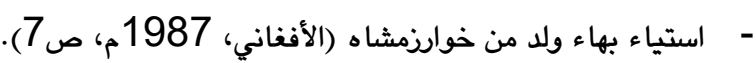

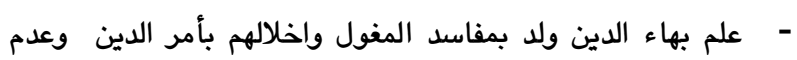

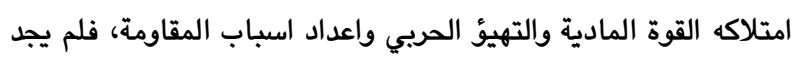
أمامه الا الهروب الى وطن آخر، وتنبيه الناس بمفاسد المغول ويأنهم يشكلون أكبر خطر على الدين لانهم ينشرون اراء لا توافق الاديان

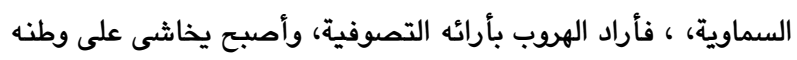
الظاهري من استيلاء المغول، ويخاف على وطنه المعنوي وهو قلعة بله

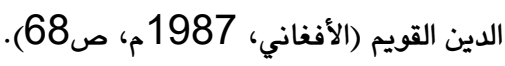

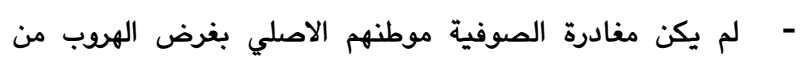
المشاكل والبحث عن الراحة فقط، بل لزعمهم أن وطنهم الثاني يساعدهم في نشر آرائهم وييسر لهم المقدرة في إصلاح الناس أكثر من قدرتهم في موطنهم الأصلي وزعمهم بأن الموطن الأصلي لا يساعدهم في تثقيف

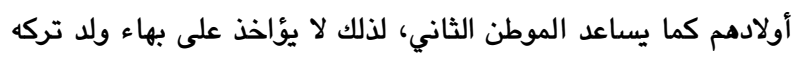
بلخ والتوجه الى الاناضول سنة (617هـ/1220م) (الأفغاني،

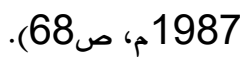
زيارة برهان الدين الترمذي الى الاناضول 
والامراء والفتوة وغيرهم من أهالي قونية (القونوي، 2000م،

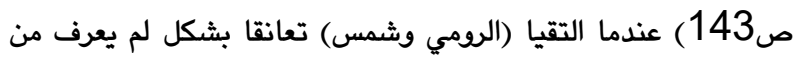

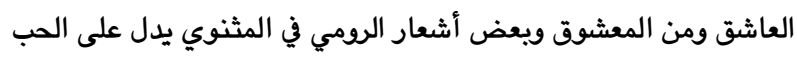
الروحي المطلق للمتصوفان فقد قال في ذلك: ليس العطشان وحده من يطلب الماء فبالمثل يتطلع الى العطشان الماء بعد رجوع شمس الدين(شيمل، 2017م، صاء48-47) عاد الرومي سيرته الاولى معه وعاد ميجانه وثوراته وأستمر في الخلوة معه، فغضب الفقهاء والمريدين العصاة من أهل الفتوة وأمالي قونية مرة أخرى على ودهي

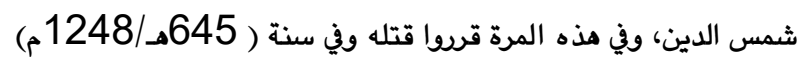
اختفى شمس نهائيا ولم يعرف مل قتل على يد مريدي الرومي أم أنه

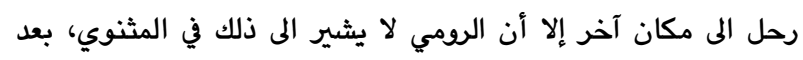
اختفائه ذهب الرومي الى دمشق عدة مرات للبحث عنه، وكان ذلك ما

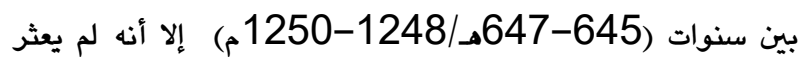
عليه (ابن بيبي، 1350ش، ص 120) وعندما يئس رجع الى قونية ويدأ بإرشاد المريدين ويرثد الامراء والفقراء والمسلمين وغير المسلمين

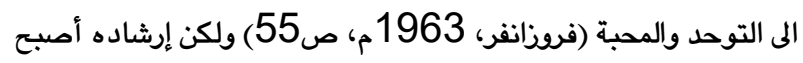
خانقاهياً وادخل في وعظه وارثاده الرقص والسماع واستمر على ذلك (الرومي، 2017م، صانقيا والمن في وعظه وارثاد). اختلفت المصادر حول اختفاء شمس الدين حيث ذكر أنه ضرب بالسكاكين من قبل المهاجمين ومن ثم أغمي عليهم ولما أفاقوا لم يروا سوى قطرات من الدم ولا يعلم كيف أختفى التبريزي، توصل بعض

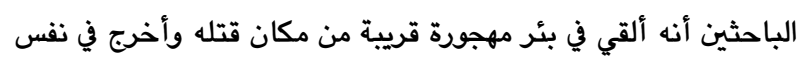
الليلة،ودفن في قونية حيث وجدوا موضع سري أعلن بعد مضي قرون

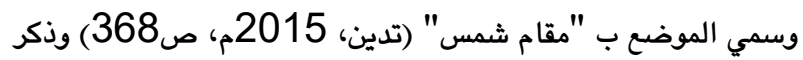
آهل مدينة "خوي " أن شمس تبريزي مدفون في خوي، وقال أهل

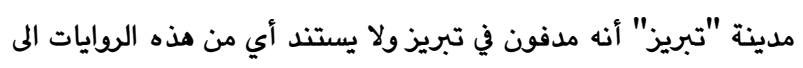

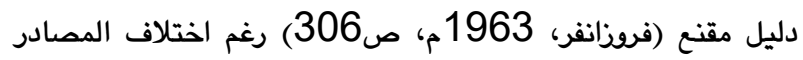
حول موضع دفنه، يمكن ترجيح الرأي الأول لأنه الأقرب الى الصواب ومو أنه مدفون في قونية. - تألم الرومي برحيل معلمه وتغزل به وخصص له ديه ديوان اطلق عليه اسمه "ديوان شمس الدين" وقال عن رحيله:

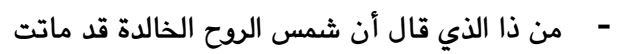
- ومن ذا الذي تجرأ على القول بأن شمس الأمل قد تولت

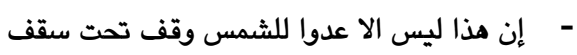
- وعصب عينيه ثم صاح ها مي الشمس تموت (ثابو، 2009م، ص36) كان التبريزي في نظر الرومي ولي من الاولياء ويمثابة المرآة التي تنعكس

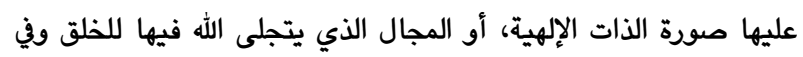
ذلك قال الرومي:"إن المسجد الذي بني في قلوب أولياء الله معبد للجميع
أمي وليس من أهل العلم (غني، 2016م، ص736) ولكن سبق أن ذكرنا بداية أن والده أرسله لتلقي العلوم والمعرفة في تبريز ودرس على اهلى يد عدد من الشيوخ، وذكر أيضاً أنه في وقت من الاوقات كان معلم للصبيان في أرضروم وقد اعترف في مقالاته بضربه للطلاب (القونوي،

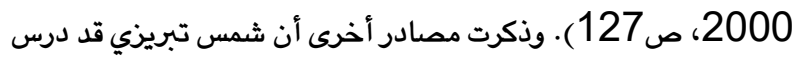
على يد شيوخ العرفان في دمشق ومنهم أبن عربي وأصبح متبحرا في

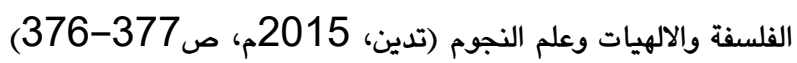
وتشير النصوص الاسماعيلية أن شمس تبريزي كان حجة للامام ركن الدي سجاسي، ومن كبار العلماء والحكماء والفلاسفة وليس اميا كما ادعى بعض المؤرخين، واذا كان أمياً كيف له أن يؤثر على عالم وحكيم

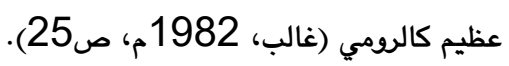
وصل الى قونية سنة (642هـ/1245م) وأستأجر حجرة في خان بيع السكر(= كاروانسه رايا شه كر فروشان) وعرف عن نفسه كتاجر وقد

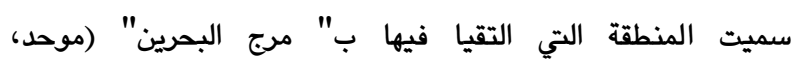

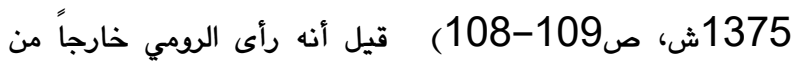

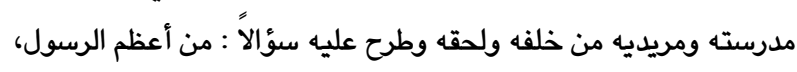
أم بايزيد البسطامي ؟ وأجاب الرومي: بدون شك الرسول أعظم وهو خاتم الانبياء فقال شمس الدين: كيف ، ومحمد قد قال : ما عرفناك حق معرفتك، وقال بايزيد : سبحاني ما أعظم شاني (ابن بيبي، 1350م، صنم118) ورغم أن سؤال شمس الدين وإجابة الرومي في غاية البساطة والسهولة بالنسبة للناس العاديين ولكن بالنسبة لعلماء كالرومي والتبريزي فإنها تحمل معاني لا يفهمها ولا يدركها غيرهم لذلك فقد أغمي على الرومي، وعندما أفاق أخذ شمس الدين الى منزله وأغلق

بابه، ويقيا أربعون يوما في الخلوة ( FÜrÜzanfer,1963)

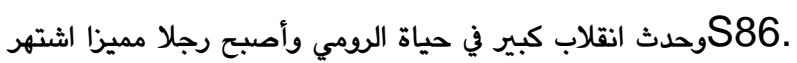

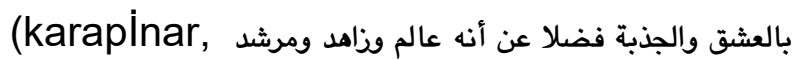

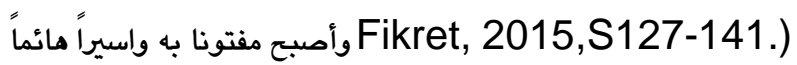
في شخصه ويعهده المظهر التام الكامل لله تعالى وكان يخلص له النية

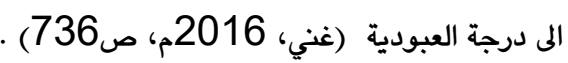
أهمل الرومي مريديه ومن عرفوه وتعلق بشمس فحقدوا عليه، لإبعاده

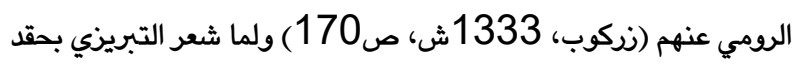
مريدي الرومي عليه قرر مغادرة قونية الى دمشق والابتعاد عن الرومي ، فتأثر الرومي بغيابه وأنشد أشعارا وأعتبر ذلك أول عهده بالشيه

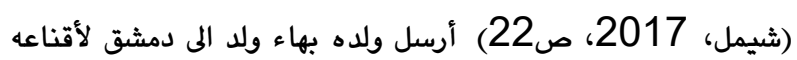
بالرجوع الى قونية وافق بالرجوع من غير اقتناع، فقال شمس:" لا أدري لماذا روحي مضطرب وقلبي غير مطمئن منذ اللحظة التي نويت فيها السفر غم موجع يأكل داخلي لا أعلم ماذا يريد مني مولانا لماذا يدعوني مئي مئي إلى مكان يريد فيه المتعصبون وعميان القلوب أن يسفكوا دمي أنتم

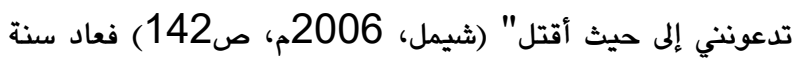
(644ه/1247م ) الى قونية واستقبل من قبل العلماء والفقراء 
أقول هذا الكلام يا شمس وإلهي

أنا قائم لشكرك يا شمس وإلهي

حتى توجه لي عنايتك يا شمس وإلهي
لإن الله فيه" فرأى في التبريزي الشخصية الإلهية والمظهر الخارجي في

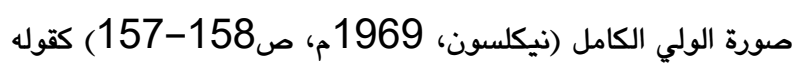
في غزليته:

$$
\begin{aligned}
& \text { شيخي ومريدي ودائي ودوائي }
\end{aligned}
$$

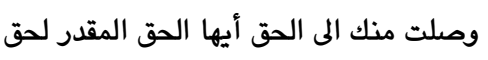

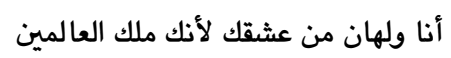

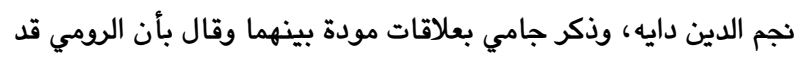

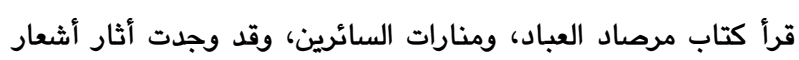

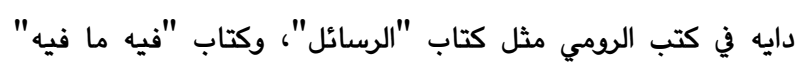

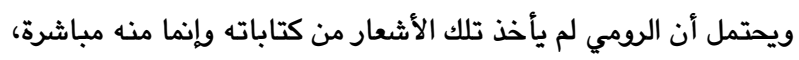
وكان يجعل من أشعاره كبداية ومطلع لغزلياته (الرازي، 1352 ألى الري،

ص71).

لا توجد معلومات أكيدة حول خروجه من الاناضول ولكن في سيرة"

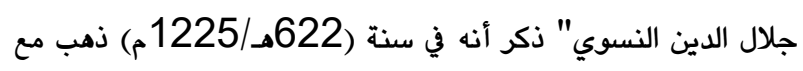
ركن الدين عطاف ممثل الخليفة العباسي الظاهر بالله إلى جلال الدين الدان

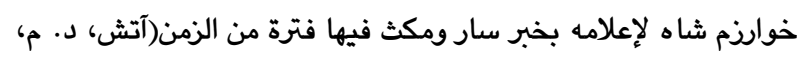

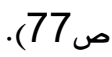

\section{ب- موقف سلاطين سلاجقة الروم من كبار الصوفية}

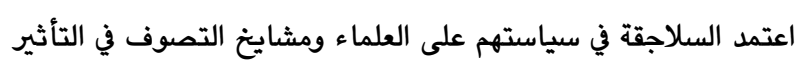
على نفوس الناس كي يتسنى لهم توطيد وتثبيت أركان الحكم ودعائمه

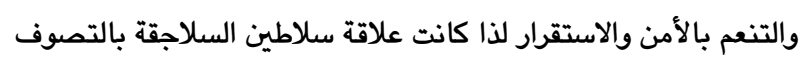

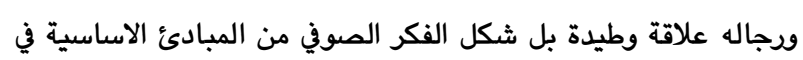

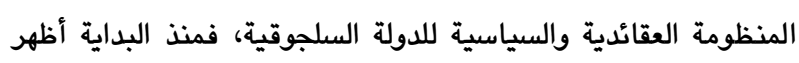

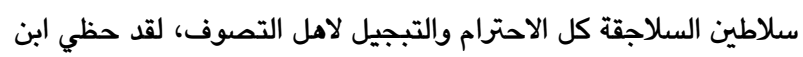

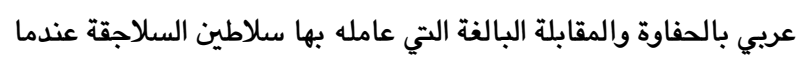

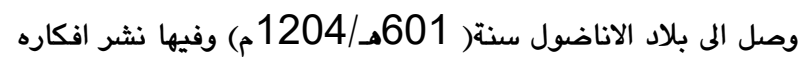

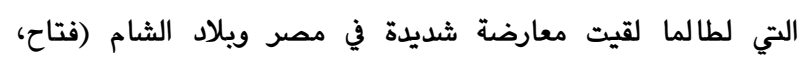

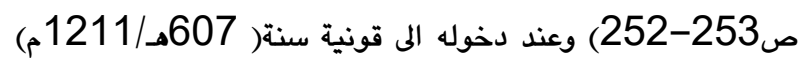

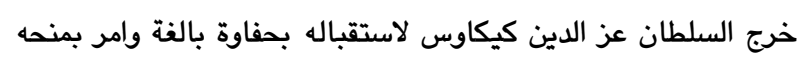
دارا فخمة(مولوي، 2010م، صنان عز السين كيكاوس).

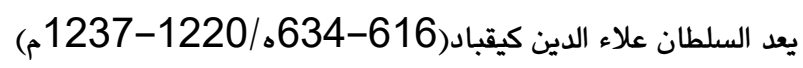

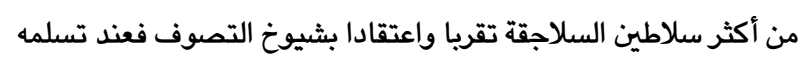
السلطة بعد وفاة أخيه عز الدين كيكاووس توجه الى عاصمة السلاجقة الستر

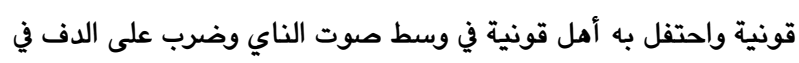

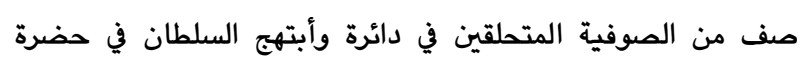

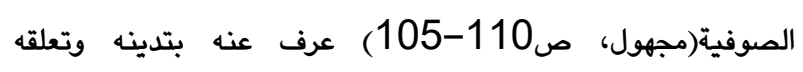
بالصوفية(فروزنفر، د. ت، ص6060) ، وأصبح علاء الدين كيقباد ملجأ

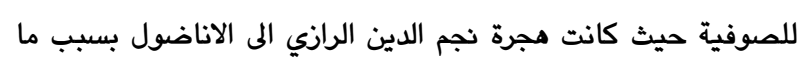

سادسا : زيارة نجم الدين الرازي(دايه)

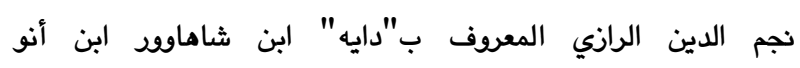

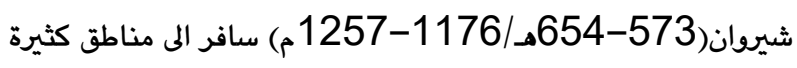
في سنة (600هـ/1203م) رجع من الحج الى خوارذم وبعد قتل شيخه

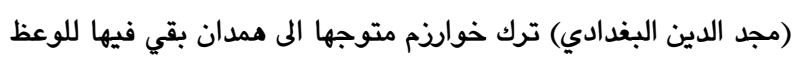

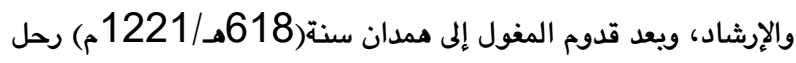

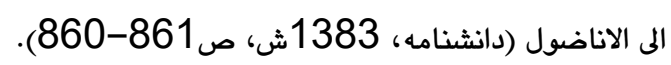

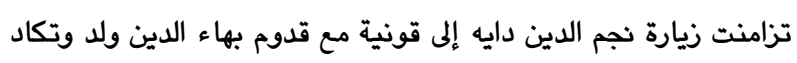
تكون نفس الاسباب لقدومهم إلى الأناضول وهي الفرار بعلمه من الغزو

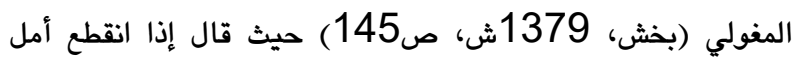

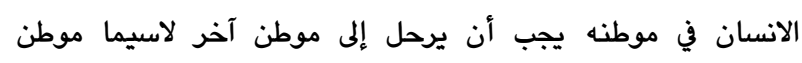

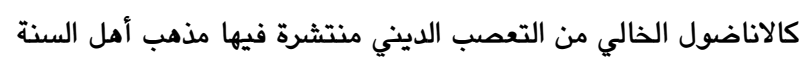

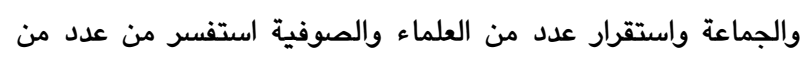

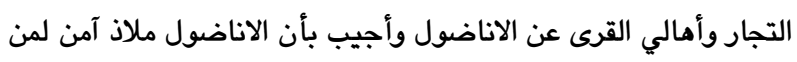

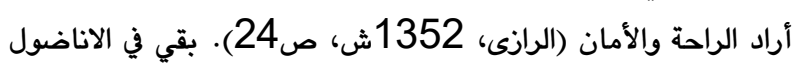

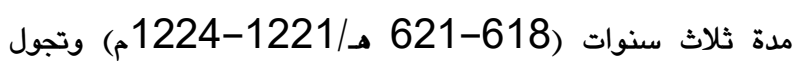
خلالها في مدنها، التقى بالسهروددي في ملطية وطلب منه قراءة كتابه

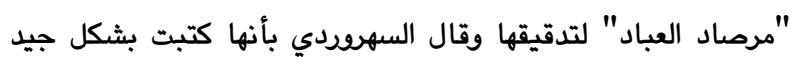

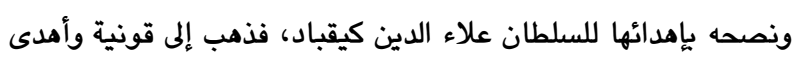
الكتاب للسلطان وسمى الكتاب"كيقباد خاتمتي" وهناك التقى بجلال

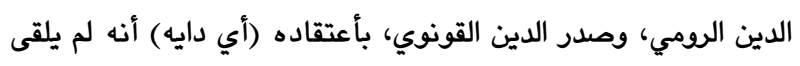

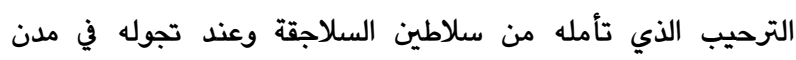

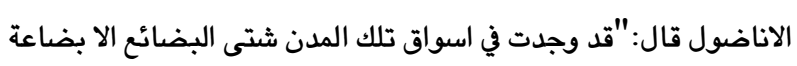
الدين وكل منود له مشترين الا أهل الحق وان جميع تعاملات البيع

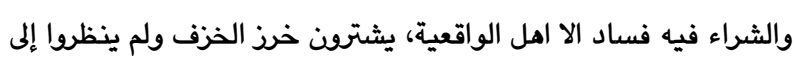

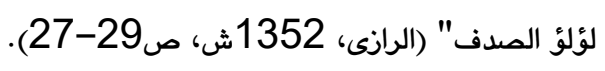

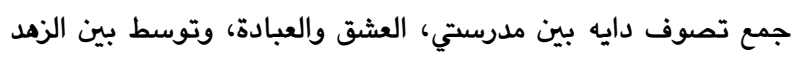

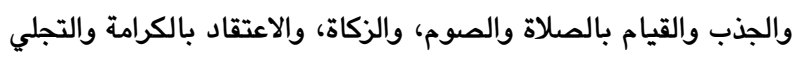

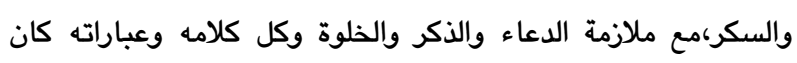

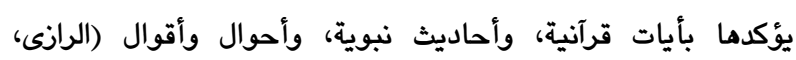

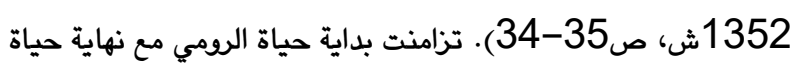


حسين ، أحلام عابد و فرست مرعي/ مجلة العلوم الانسانية لجامعة زاخو، مجلد:9 ، العدد:3 ، ص 476- 491 ئيلون- 2021.

ضمت جميع العلوم التي عرفتها الحضارة الاسلامية من تصوف وعلوم

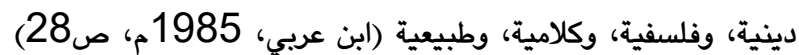

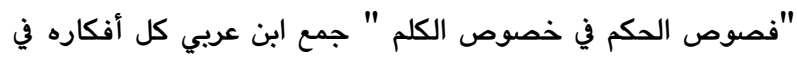

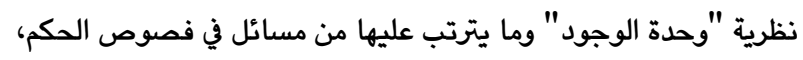
وأصل هذا الكتاب قائم على أساس رؤيا كما يدعي لذلك بقوله:"أما بعد : فأني رأيت رسول الله عليه السلام في مبشرة أريتها في العشر الآخر من المحرم سنة سبع وعشرين وستمائة بمحروسة دمشق، وييده صلى

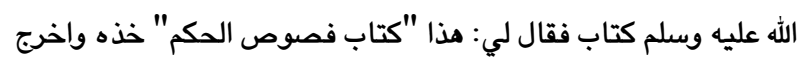

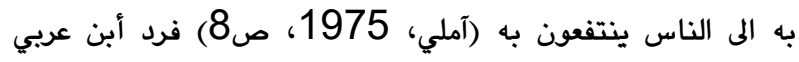

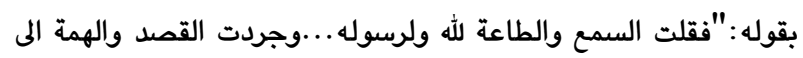

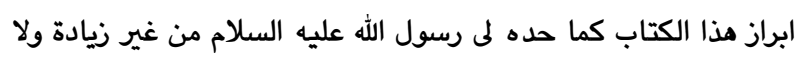

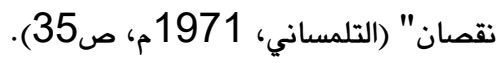

ومن كتبه أيضا:

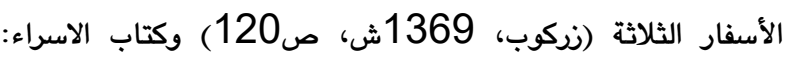
وصف فيها اسرائه ولم يكن بجسده بل بروحه، وكتاب روح القدس:

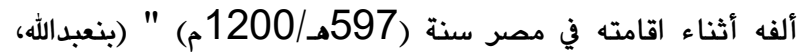

$$
\text { 2001، ص201-40). (20) }
$$

ترجمان الأشواق (= تفسير الرغبات) (الياد، د. ت، ص152). 1520) يضم

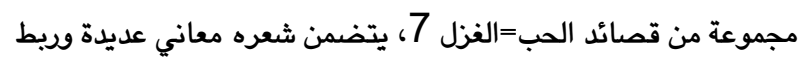
بين الجمال الانساني، والحقيقة المقدسة، والغالب على قصائده الجمال الانثوي وأورد فيها تعليقات على قصائده يوضح فيها بعدم خروجه في النيان

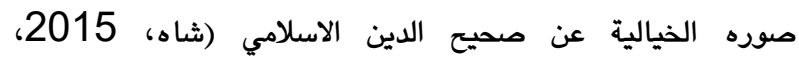
ص256). أما الفترة التي قضاها ابن عربي في قونية كانت فترة هادئة

نسبيا فاستأنف الكتابة والتأليف، والكتب التي ألفها في قونية:

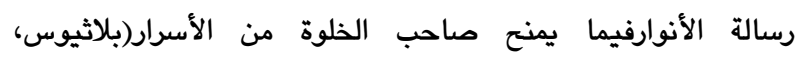
1965م، ص66) والتي أوضح فيها كيفية دخول المريدين في الخلوة بدأ كتابتها في قونية وأكملها في دمشق من السنة نفسها

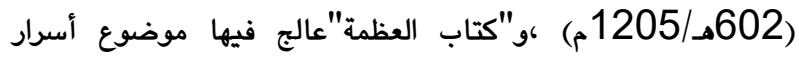
الحرف، و"رسالة الأسرار"، و"كتاب الأمر" (حاج يوسف، 2006، ص297) ، و"مشاهد الأسرار القدسية ومطالع الأنوار الالهية

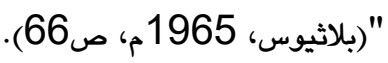

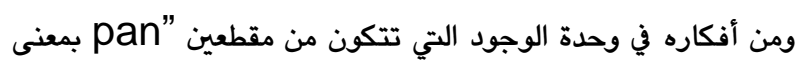

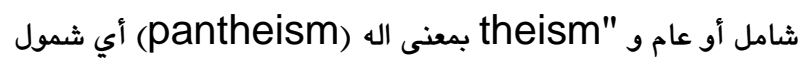

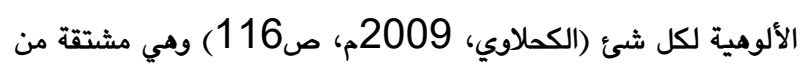

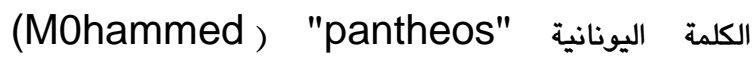
Rustom,p63. وهو موضوع يعسر فهمه على من ليس من أهل الطريق ويؤدي الى سوء الفهم، والتوصل الى نتائج خاطئة ورمي القائل

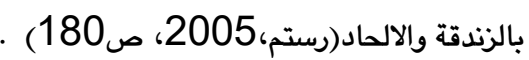
انبثقت فكرة وحدة الوجود من ما يسمى ب "الاتحاد والحلول" الاتحاد: هو تشبيه الخالق بالمخلوق، والحلول: وهو تشبيه المخلوق بالخالق
سمع عنه ومعاملته الطيبة للعلماء والصوفية ورحل اليها بصفة مؤقتة لحين انتهاء الغزو المغولي لبلده واحسن السلطان وفادته واهداه الرازي

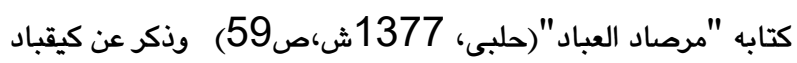
انه دعا بهاء ولد عندما كان في بغداد للمجئ الى قونية لما سمع عنه

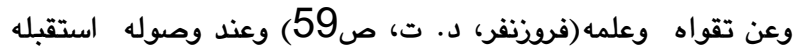
السلطان بكل احترام واجلال ودعاه للاقامة في قصره ولكن الشيخ

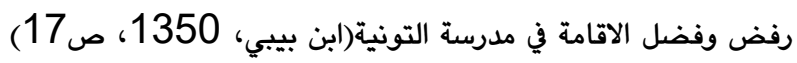

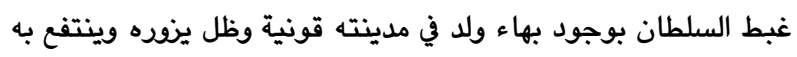
ومن مجالسته ويسبب الاحترام والتقدير الذي لقيه بهاء ولد من السلطان فهو بدوره أيضا كان يكن له الاحترام واحيانا كثيرة كان يناديه

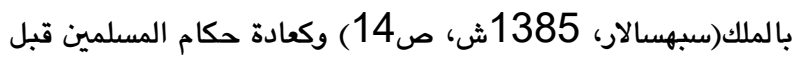
خوضهم الحروب طلب الدعاء من مشايخهم المعتقدين بهم فقبل ذهاب علاء الدين كيقباد خوض معاركه كان يذهب الى بهاء ولد للتبرك ويطلب الدعاء له ولجيشه بالنصر على الاعداء 6. بعد وفاة بهاء ولد وجد ابنه جلال الدين الرومي الاهتمام من قبل

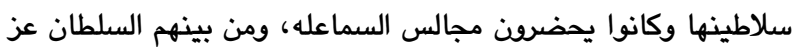

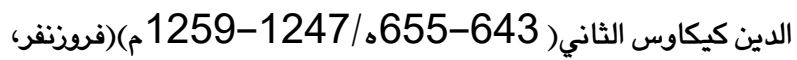

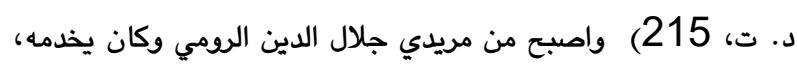

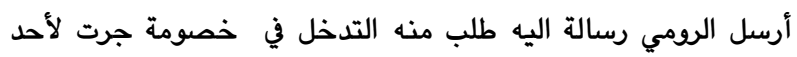

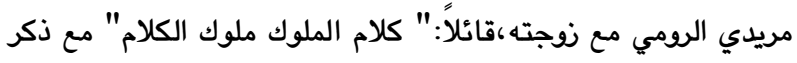

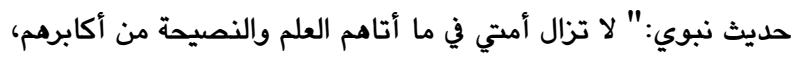

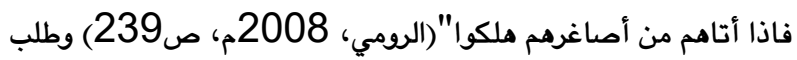
السلطان منه العون ضد أخيه ركن الدين، وكان ركن الدين وزوجته

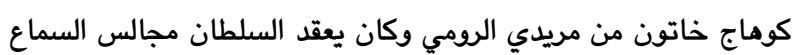

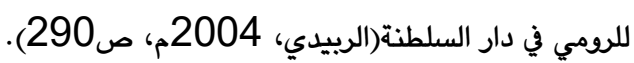
ج: مؤلفاتهم وأفكارهم وتأثيرهم على المجتمع الأناضولي

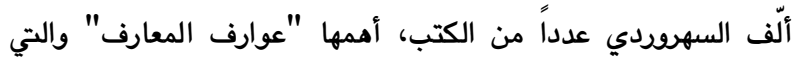

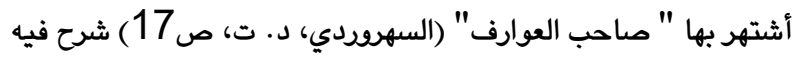

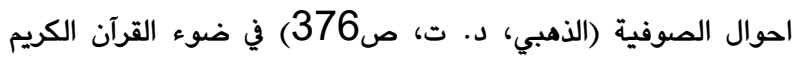

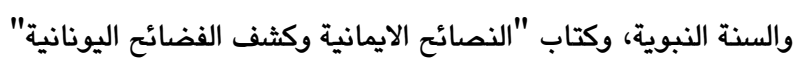
حيث ناقش في هذا الكتاب حجج الفلاسفة ودحضها باسانيده وادلته التي تكون في الغالب على الطريقة الوعظية الصوفية بعيدا عن متامات

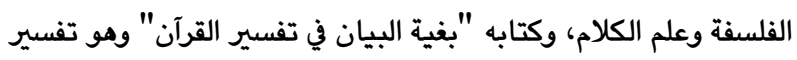
للقرآن الكريم اختار من كل سورة ما أشكل من الفاظها وآياتها وذكر ولهر

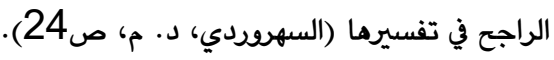

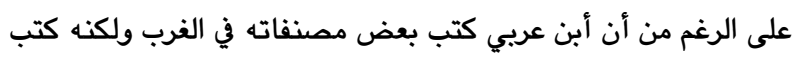
القسم الاكبر منها في الشرق، حتى بلغت المئات من الكتب والرسائل بلغ عندائل

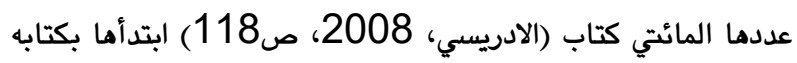

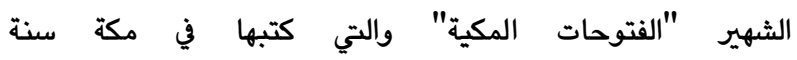
(599هـ/1202م) أي بعد سنة من رحلته الى الشرق، وتعد موسوعة فيهات 
حسين ، أحلام عابد و فرست مرعي / مجلة العلوم الانسانية لجامعة زاخو، مجلد:9 ، العدد:3 ، ص 476- 491 نيلون- 2021.

لذا من الصعوية بمكان تحديد عقيدة ابن عربي على وجه الدقة حيث أنه مزج بين الدين، والفلسفة، والتصوف "(1)، ويعد أقرب القائلين بوحدة الوجود الى روح الاسلام والبعض انكروا عليه القول بوحدة الوجود وعدوا اقواله في وحدة الوجود شطحات صوفية أو يعتبرونها

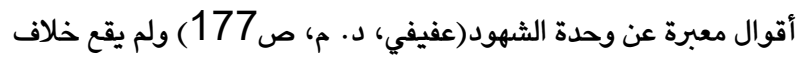
في شخص كما أختلف في ابن عربي، حيث عده البعض صوفي بارذ

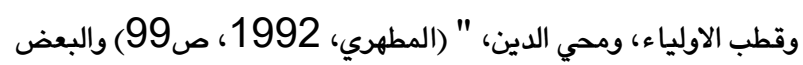
من الفقهاء عده قطب الكفر والزندقة، ومميت الدين، وماحي الدين

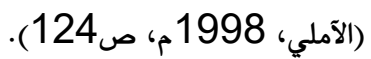

ذكر بعض الباحثين أن مسألة وحدة الوجود عند ابن عربي هي ثمرة ما توصل اليه بعد تفكره بالقرآن الكريم والسنة النبوية، ثم شهوده لهذا التفكر بقوله:"...الوجود كله واحد في الحقيقة ...فلو تتبعت الكتاب والسنة ما وجدت سوى واحدا ابدا وهو: الهو..." ،لذلك أعتبر البعض أبن عربي مفكر مقيد بالكتاب والسنة يقول في ذلك:" لقد آمنا بالله ورسوله وما جاء به مجملا ومفصلا مما وصل الينا من تفصيله، وما

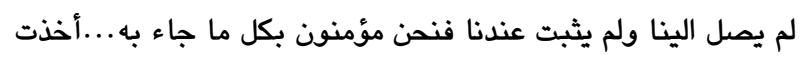
ذلك من أبوي أخذ تقليد...فعملت على ايماني بذلك حتى كشف الله عن بصري ويصيرتي وخيالي...فصار الأمر لي مشهودا والحكم المتخيل المتوهم بالتقليد موجودا...فلم أزل أقول وأعمل ما أقوله واعمله لقول النبي صلى الله عليه وسلم....لا لعلمي، ولا لعيني، ولشهوده (ابن عربي، د. م، ص323).وقال أيضا :" ...ان علم الشريعة المحمدية بعد ولديك

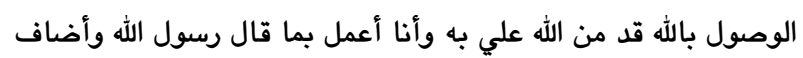
الولي محقق للشريعة المحمدية عن الحق سبحانه بطريق اليقين " وكان

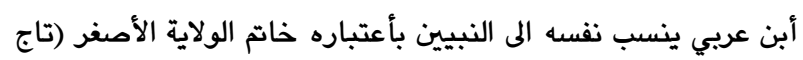

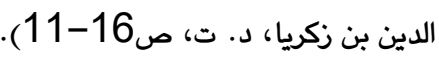
رغم تنسيب اكتمال صيغة نظرية وحدة الوجود الى ابن عربي (السهلي، 2005، ص55) لكنه لم يصرح في كتاباته بعقيدته في وحدة الوجود غير تلميحات لخوفه من أن يكون مصيره كمصير الحلاج كقوله في ذلك:

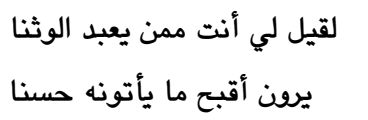

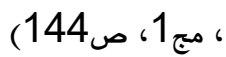

تفسير أو وصف، ويطلق عليه الصوفية المسلمين "بالفناء" (شرف، 1991، ص 334-332) أما عن فكره في وحدة الاديان فقد أعتبر ابن عربي الدين الاسلامي دين شمولي والديانات السابقة ما مي الا تمهيد

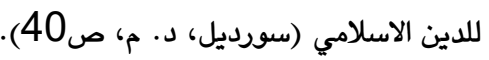

(شرف، 1991، ص334) وقد دافع البعض عن الصوفية الذين

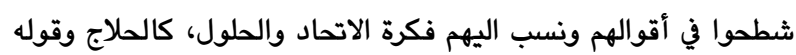
"أنا الحق"، أو "ما في الجبة غير الله"، وقول أبي يزيد البسطامي "سبحاني ما أعظم شاني"، حيث ذكر بأن ذلك لم يكن تأليه لذواتهم وإنما كان وصولا ذوقيا الى حقيقة أنه لا يوجد في مذا الوجود الا مو لون وأفعاله ، وصفاته، وليس لهم وجود من أنفسهم، بل كل ذرة من وجودهم هي في الواقع وجود الله فهم قائمون به، وفيه، ومنه، واليه مستندين في

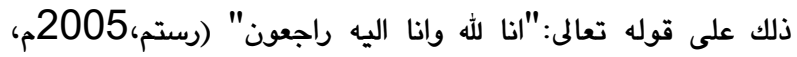

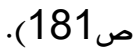

فقصد العرفاء قولهم بوحدة الوجود أي بمعنى وحدة الموجود، والطريق اليها طريق قلبي شهودي، وليس طريقا تصوريا عقليا، ولا يقصدون اتحاد وجود الواجب (= الله ) والوجود الامكاني (= الانسان ) فذلك كفر بلا شك، انما يقصدون رؤية قلبية شهودية تصل الى مرحلة لا ترى الا الله أي مشاهدة الحق في كل شئ وسريان سره في كل شئ (زكي،

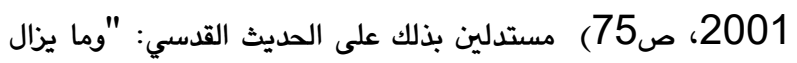
عبدي يتقرب الي بالنوافل حتى أحبه فاذا أحببته كنت سمعه الذي

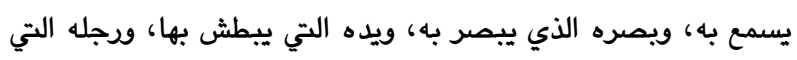

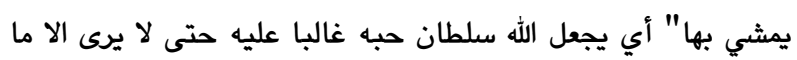
يحبه الله (محمد القاري، 1971م، صبهي 143) والمفهوم من الحديث هو التوفيق والهداية والسداد من الله تعالى بتوكل المرء عليه.

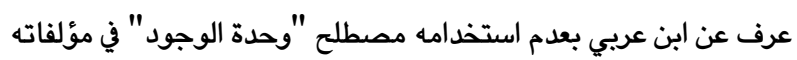
وكان أبن تيمية (M0hammed Rustom,w.d, p53. ) أول من أطلق المصطلح على تصوفه ورماه بالكفر(الكحلاوي، 2009، ص115) وفسر علماء صوفية المسلمين أن الصوفي الذي يشير بالألغاز الى الأتحاد مع الله أن مراده بالأتحاد هو شهود وجود

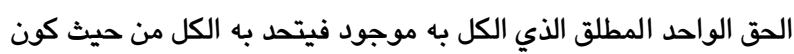
كل شئ موجودا به معدوما بنفسه لا من حيث أن له وجودا خاصا أتحد به فأنه محال ولهذا الموجود الواحد ظهود وهو العالم بما يحويه (المسيري، 1983، صانه مال ولهذئ 139).

$$
\text { ولا رب جوهر علم لو أبوح به }
$$

ومن ترسبات وحدة الوجود هي وحدة الشهود، ووحدة الأديان، فوحدة

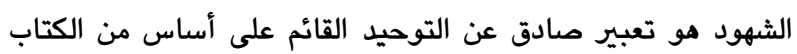
والسنة، ومو اتصال روحي بين العبد وربه وتؤكد فكرة الثنائية بين

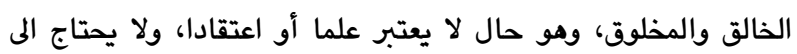


فمرعى لغزلان ودير لرهبان والواح توراة ومصحف قرآن

ركائبه، فالحب ديني وايماني

بالمثنوي ايضا لأنه ذو وجهين، ظاهري وفيه يبين الشريعة والطريقة

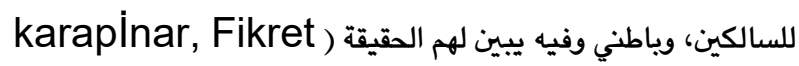

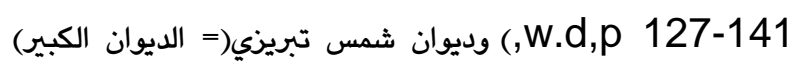

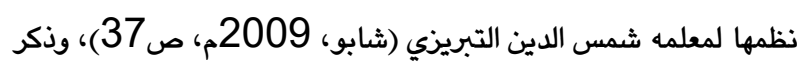
أبن بيبى المعاصر لدولة سلاجقة الروم أنها كتبت باللغة الفارسية والعربية، ويعض الملحقات التركية واليونانية وأشار أن قوة تأثير أشعار الرومي على القارئ هي بمثابة التأثرعند قرآءة الكتب السماوية (ابن واتئ بيبى، 1350ش، ص119 119 ورياعيات جلال الدين الرومي: وفيها حقائق صوفية على شكل قصص وحكايات (الأفغاني، 1987 1987،

وذكر حلبي كتاب آخر للرومي وهو: "مصاحب العارفان " كتبه باللغة

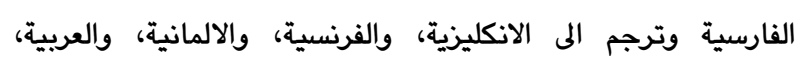
والاردية، وقال أن أوضح نسخة هي النسخة الانكليزية ويتضمن ست ولى والى

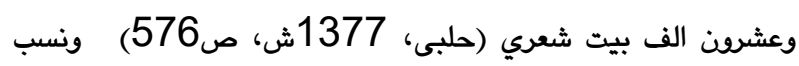
بروكلمان كتابين آخرين له وهما: اوراد كبير وصغير، وحقائق أذكار

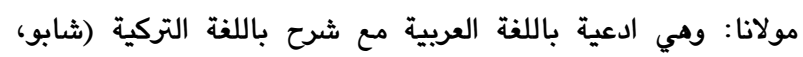

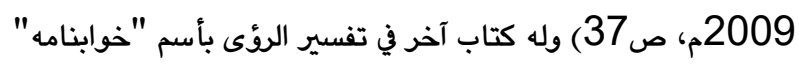

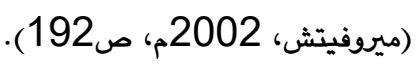

بدأ جلال الدين الرومي بكتابة الشعر سنة (642هـ/1245م) في عمر الثمان وثلاثون سنة، أي عندما عاش حالة عشق مع شمس التبريزي، فبداية كتب الغزل والتي كتبها في ديوان شمس ومن ثم بدأ بعدها بمرحلة

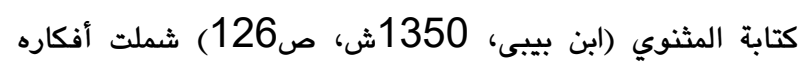
وموضوعاته مختلف جوانب أمور الحياة اليومية، وصاغها بشكل فني

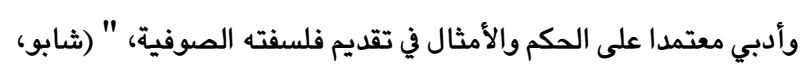

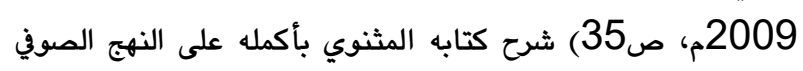
بقالب شعري وذكر أيضا أنه كان عالم بالموسيقى والعزف على الناي

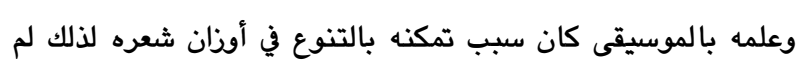
يتمكن أحد استخدام أوزان شعرية كالتي عند الرومي (ابن بيبى، بانيك

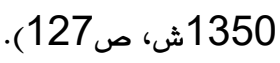

الشعرعند الرومي ينقسم الى قسمين: شعر تعليمي: محوره الانسان والاخلاق ويعتني بالمثل العليا للحياة الانسانية والكون وله شعر لطيف حول عدم انتمائه الى اللامكان وأنه

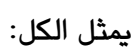

$$
\begin{aligned}
& \text { وقد أعتبر كل الطرق تؤدي الى الله الواحد، بقوله: } \\
& \text { لقد صار قلبي قابلا كل صورة } \\
& \text { وييت لأوثان وكعبة طائف } \\
& \text { أدين بدين الحب أنى توجهت }
\end{aligned}
$$

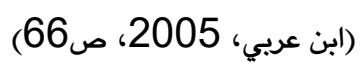

وقد ذكر المدافعون عن فكرة وحدة الأديان بعدم التفاخر في تعظيم رسول عن رسول آخر، وعدم تكذيب دين من الأديان ويجب احترامها وتقديسها وفهمها على حقيقتها لأنها من ذات المصدر (المسيري،

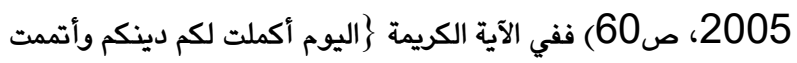
عليكم نعمتي ورضيت لكم الاسلام دينا (سورة المائدة، الآية) فأخبر الله تعالى أنه أكمل للمؤمنين دينهم في ذلك اليوم (المروزي، د. م،

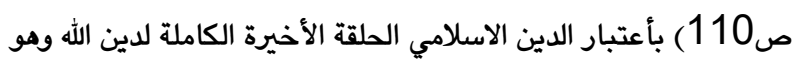
جزء متمم ومكمل للأديان السابقة له فأنه بهذه الصفة جاء لينظم

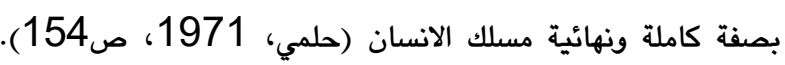
الحقيقة المحمدية8، أو النور المحمدي9: فلسفته في ذلك بلوغ الاولياء درجة الأنبياء عن طريق التجلي النوراني، والنور المحمدي عند ابن عربي يشمل جميع الأولياء سواء أكانوا من آل البيت أو من غيرهم ويدلل على ذلك بدخول الصحابي سلمان الفارسي بمثل هذا النور (عبدالله حسن، 2017، ص342).

أما الرعي ألّف كتب شعرية ونثرية لإلمامه الواسع بالثقافة السابقة لعصره كالميثولوجيا اليونانية، والايرانية وأفكار بطليموس، وعلوم التفسير، والصديث، وعلم الكلام، والمنطق، واللغة، والأدب ،والعلوم

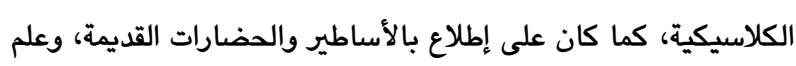

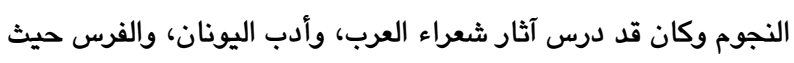
تبرز في آثاره ثقافته العامة لا سيما في المثنوي واعتمد في كتاباته على حكايات واعتقادات العامة وهدفه من تلك الكتابات تعليم العامة ( تبردي حسون، 2011م، صات144-143). مؤلفاته النثرية هي: مجموعة الرسائل: التي عرفت ب "مكتويات مولاناي روم" وهي رسائل أرسلها الم معاصريه من الاصدقاء (غني،

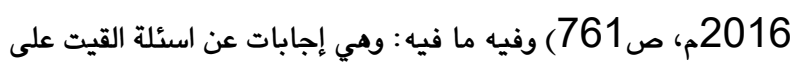
الرومي في مناسبات مختلفة وكان يدونها ولده سلطان ولد أومريديه

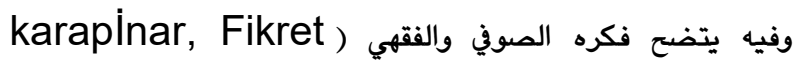

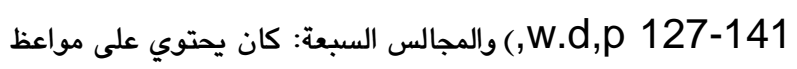
وخطب القاها على المنابر (الأفغاني، 1987م، ولم، ص111).

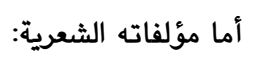
المثنوي: أهم آثار الرومي وأطلق عليه البعض "صقيل الارواح" (حلبى، 1377 ش، ص575) وفي ايران سمي ب"جامع القرآن" (ترمنجهام، 1994م، ص108) هو عبارة عن النظم الذي يراعي فيه توحيد

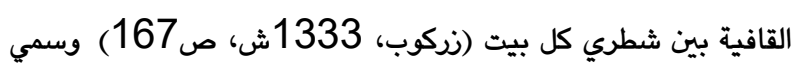




\author{
نه ترسانه يهوديم من نه كبرم نه مسلمانم \\ نه از كان طبيعيم نه از افلاك كردانم \\ نه از ملك عراقينم نه از خاك خراسانم
}

نه تن باشم نه جان باشم كه من از جان جانا نم

الرومي في كتاباته أن سبب ظهور المذاهب هو سوء فهم وحدة الوجود، وقال يجب على الانسان الرجوع الى طبيعته وأساس خلقه لتفادي ظهور

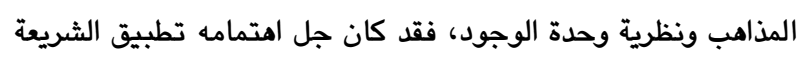

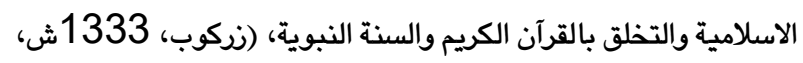

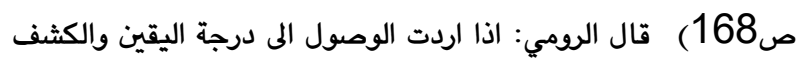
يجب السير وفق الكتاب والسنة وعدم السير وفق اختلاف المذاهب،

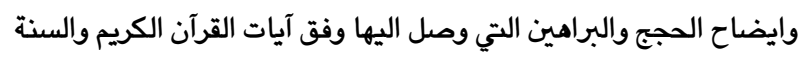

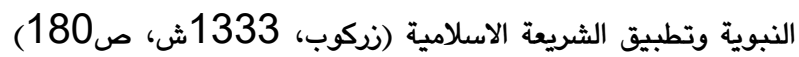
وأحيانا يدل شعره على عشقه الالهي الممزفج بفكرة الوجود الواحد كقوله:

فلو ذهبت الصورة فلا فرق ما دام أصلها واحد

مواضيعها شملت كافة المجالات: الطب، الفلسفة، علم الكلام، الفلك، قصص القرآن، والحديث النبوي، والقصص الشعبية والشطرنج (ثابو،

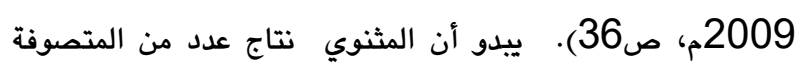
فالاشارات والرموز والافكار لبرهان الدين، والالهام من شمس الدين،

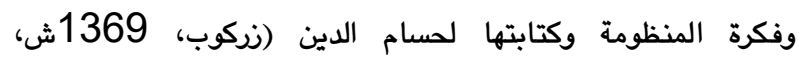

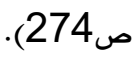
وقد ألف دايه مرصاد العباد بطلب من مريديه ويسبب أسفاره الكثيرة لم يستطع اتمامه الى أن ذهب الى الاناضول اكملها وكتب مصنفه الآخر"

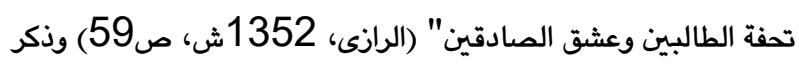

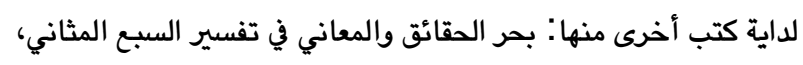
وكشف الحقائق وشرح الدقائق، ومعيار الصدق في مصداق العشق (الباباني، 1971 م، صك420) يمكن أن يكون له آثار كثيرة ولكنها ضائعة ويرجع السبب الى الفتن الكثيرة في ذلك العصر (الرازى، 1352ش، ص50).

في تلك الفترة تمكن العديد من شيوخ التصوف من ذوي الأصول

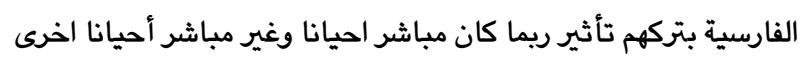
على نشر طرق صوفية جلبوها في ايران ويلاد ما وراء النهر. وأصبحت

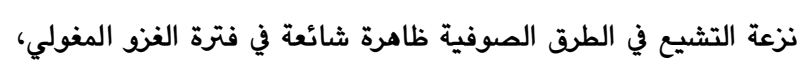

$$
\begin{aligned}
& \text { جه تدبير اى مسلمان كه من خود رانمى دانم } \\
& \text { نه شرقيم نه غربيم نه بريم نه بحريم } \\
& \text { نه از مندم نه از جينم نه از بلغار وسقسينم }
\end{aligned}
$$

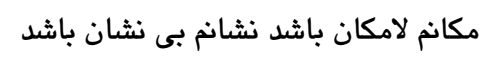

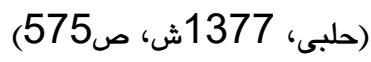

شعر روحي: وفيها يدود شعره حول المعاني الصوفية من وجد ونفس انسانية وارتباطها بالاصل الالهي بعيدا عن الحياة المادية (ثـابو، 2009م، ص35) وذهب البعض ومنهم نيكلسون أن جلال الدين الرومي لم يكن من القائلين بوحدة الوجود، بل هو من الذين تغلبت عليه

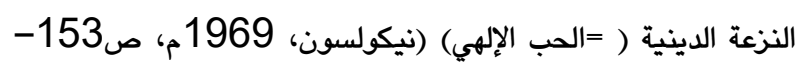

وقد ذكر أن جلال الدين الرومي لم يكن ملماً بالتصوف ويوحدة الوجود

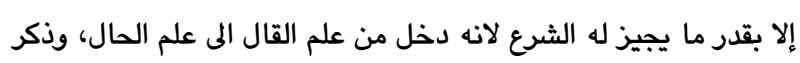
إبن بيبى أن الرومي كان يؤمن بوحدة الوجود فقد كان يرى أشكال

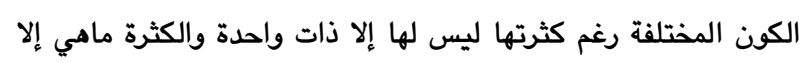
اعتبار أو تجلي للواحد (ابن بيبى، 1350ش، صغنرتهان ل138) وأوضح

إن كل صورة رأيتها فجنسها في اللامكان

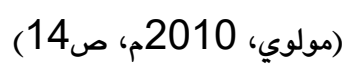

ولم يكن الرومي يعتقد بوحدة الأديان وكان يرى أن الدين عند الله هو

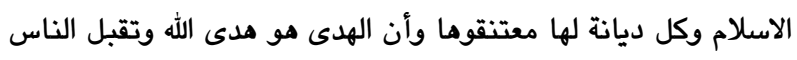
للهدى متفاوت ( حسن، د. م، ص 67-66) كقوله: مسلم أنا ولكني نصراني ويرممي ونرادشتي توكلت عليك أيها الحق الأعلى فلا تنأ عني ويت وني ليس لي سوى معبد واحد أو مسجد أو كنيسة أو بيت صنم ووجهك الكريم منه غاية نعمتي فلا تنا عني لا تنأ عني كان الغرض من تأليف المثنوي أن ييقى الى الأبد وأن تناسب جميع

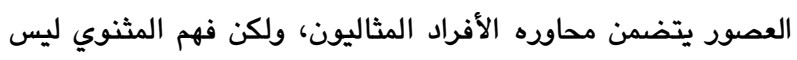

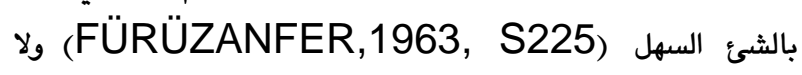
يتطلب فقط معرفة اللغة الفارسية ومعرفة العقائد الاسلامية وفهم الشعر بل يتطلب أن يكون القارئ له معلومات واسعة عن المعارف الاسلامية (ابن بيبى، 1350ش، صنيط 129 يكون يعد شعر المثنوي من أرقى الأشعار دون الرومي المثنوي على غرارالشعر العربي ووجدت فيها أبيات شعرية مترجمة حرفيا لشعر المتنبي، وهي موسوعة كاملة وواحدة من أكبر كتب التصوف الاسلامي وقطعة أثرية جمعت التفاصيل الدقيقة للأمم السابقة (FÜRÜZANFER,1963, S145-147) 
حسين ، أحلام عابد و فرست مرعي/ مجلة العلوم الانسانية لجامعة زاخو، مجلد: ، العدد:3 ، ص 476- 491 نيلون- 2021.

معتقداتهم القديمة (الشامانية)على أفكارهم ومعتقداتهم، وموقع

الاناضول

سابعا: تزامن وفادة بعض الصوفية الى الأناضول كإبن عربي، وأوحد

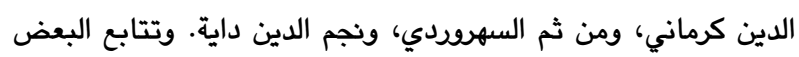

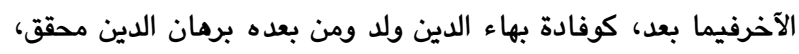
ومن ثم شمس التبريزي. ثامنا: زرع شيوخ الصوفية روح الجهاد في نفوس المجتمع التركماني.

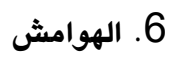

1- السماع: مصطلح صوفي ويقصد به ما يرتل من اشعار واذكار على وقع الناي

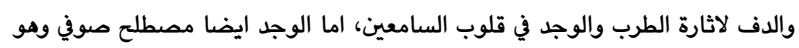

ما يرد على القلب دون تصنع ولا تكلف. مجهول، اخبار سلاجقة الروم، صل118. 2- الجمال الإلهي: لم يكن بعض الصوفية بعيدين عن عالم المجاز حيث اعتبر بعضهم

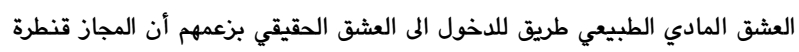

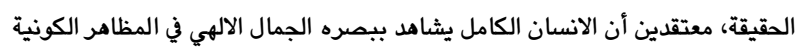
الحسية كرؤيته المظاهر الروحانية بعين البصيرة، واعتبروا للجمال الالهي وكماله

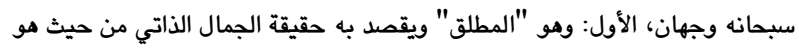

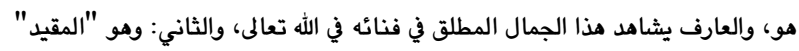

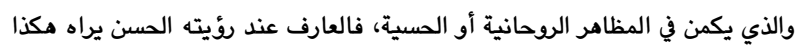

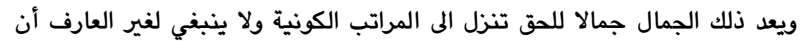

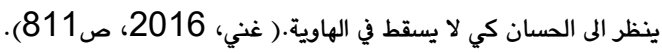

3- بلخ: إحدى مدن خراسان، كانت في العهود القديمة مركزاً للبوذية ويدون شك أن

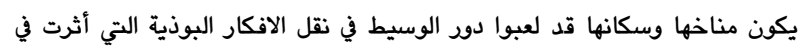

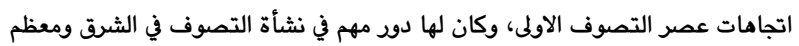

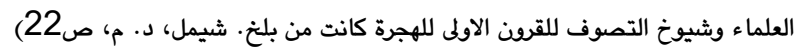

4- فقد لقبه والده ب "خدواندكار" أي السلطان. ودعوه ب "مُلًا هنكار"، و"مُلاّ

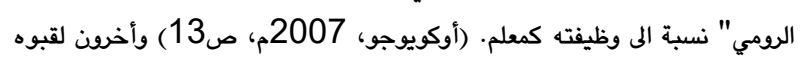

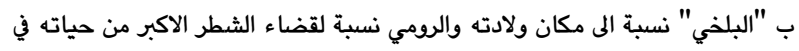

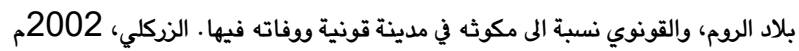

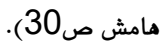
5- أدعى شمس تبريزي أنه تسلم خرقة التصوف من النبي مباشرة على أنها ليست

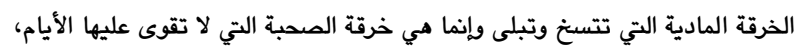

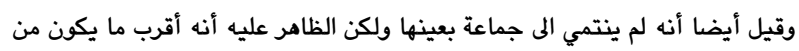

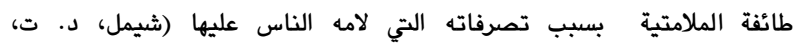
ص22،43). 6- وفق رواية سبهسالار عند مكوث علاء الدين بالقرب من عسكر خوارزمشاه كان

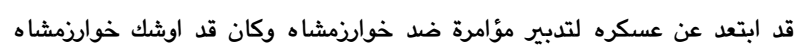

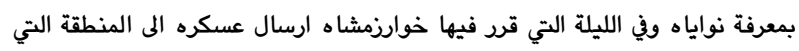

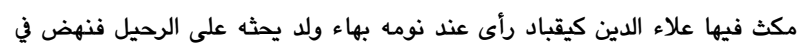
ساعته والتحق بعسكره وعندما وصل عسكر خوارزمشاه الى المنطقة لم يجدوا أحدا.

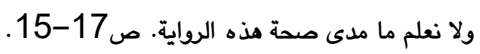

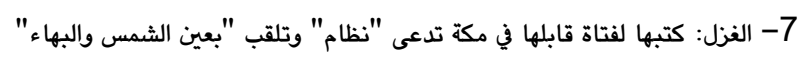

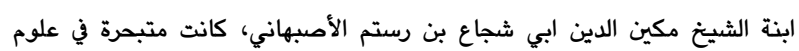
الشريعة، محي الدين ابن العربي، ترجمان الأشواق، رينولد نيكولسون الاهبه الندن:
حتى أصبحت ظاهرة الولاء العلوي وانتشار الاتجاهات الشيعية في الحركة الصوفية التي نشطت في اوساط الفرس وقبائل التركمان في ايران وهضبة

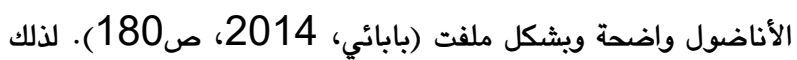
كان من السهل ظهور تصوف ذات الطابع الشيعي في الاناضول خاصة بعد ضعف الخلافة العباسية وغزو المغول لمناطق العالم الاسلامي، والدهشة التي أصيب بها المسلمون ورغبتهم النجاة من هجماتهم، فوجد وفيد الشيعة أن الوقت مناسب لتويج أفكارهم الشيعية في الاوساط السياسية

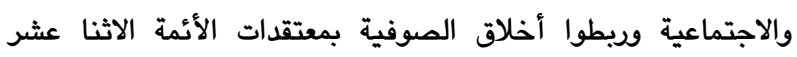

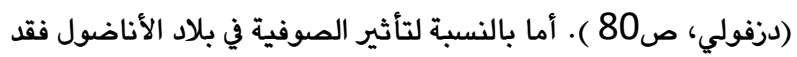
عرف عن الرومي بتعاطفه مع مسيحي ويهود قونية وكانو ا يعدونه موسى وداوود ويسوع عصره وكانوا أتباعه وتلاميذه ففي حياته

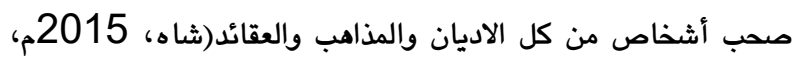

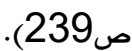

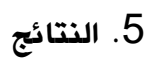

يمكن تلخيص أهم النتائج التي توصلت اليها الدراسة بالنقاط التالية:

أولا: أصبحت الأناضول وجهة الصوفية لما عرف عنها بإحتواءها لجميع الأديان، والأفكار، والأراء والمذاهب، وما عرف عن سلاطينها بتسامحه تجاه الاديان الاخرى، وإحترامهم وتقديرهم للصوفية والعلماء.

ثانيا: وفود الصوفية من مختلف المناطق من خراسان والعراق والشام وغيرها، ومعظمهم كانوا من أصول فارسية الأمر الذي أدى الى انتشار

$$
\text { التصوف الفارسي في الأناضول. }
$$

ثالثا: لم يستقر مقام أولئك الصوفية في الأناضول باسثناء بهاء الدين ولد ومن بعده ابنه جلال الدين الرومي واولاده وأحفاده، ولا زالت أضرحتهم في قونية مزار للصوفية من كافة أنحاء العالم الاسلامي والغربي. رابعا: إحدى خصوصيات التصوف في الاناضول والصوفية الوافدين إليها، تتلمذ بعضهم على البعض الآخر، وعدم اقتدائهم ببعض، واستقلالهم الفكري عن نظرائهم الآخرين بتصوف خاص. خامسا: ما ميز تصوف أولئك هو تصوف الحب الالهي، أو ما يسمى

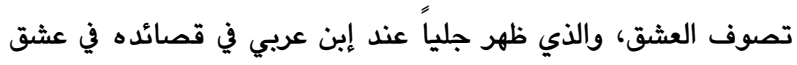
النساء، وكتصوف جلال الدين الرومي ومثنوياته في عشق للرجال،

$$
\text { وعبادة الجمال (= عشق الغلمان) كتصوف أوحد الدين كرماني. }
$$
سادسا: من خلال الدراسة تبين أن التصوف العرفاني الفلسفي كان الأكثر إنتشارا من التصوف النظري، والسلاطين كانوا متحيزن الى جانب التصوف العرفاني الفلسفي أكثر من التصوف النظري، وذلك بسبب بقاء تأثيرات بيئة الاناضول ذات الطابع المسيحي، فضلًا عن 
حسين ، أحلام عابد و فرست مرعي/ مجلة العلوم الانسانية لجامعة زاخو، مجلد:9 ، العدد:3 ، ص 476- 491 نيلون- 2021.

مرقاة المفاتيح، ويهامشه، شرح مشكاة المصابيح، لمحمد بن عبدالله الخطيب كيب التبريزي، كتاب الدعوات/باب ذكر الله عز وجل والتقرب اليه، تحقيق: جمال

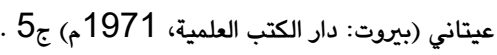

مجهول، مؤلف (من مؤلفات القرن السابع الهجري).

أخبار سلاجقة الروم، مختصر سلجوقنامه ، ترجمه: محمد السعيد جمال الدين( موله

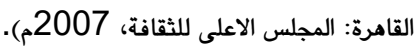

المروزي، محمد بن نصر (294هـ/906م) 14 كتاب الصلاة (د.م: د.ت)

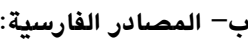

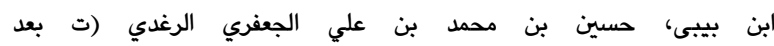

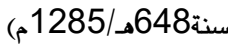

الاوامر العلائية في الامور العلائية" باهتمام: محمد جواد مشكور (تهران: (1350

أقسرائي، محمود بن محمد بن عبد الكريم (ت اواسط القرن الثامن الهجري) تاريخ سلاجقة، مسامرة الأخبار ومسايرة الأخيار، باهتمام وتصحيح، عثمان توران (تهران:

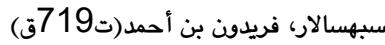
رساله سبهسالار در مناقب حضرة خداوندكار، تصحيح: محمد افشين وفايى(تهران:انتشارات سخن،1385ش) لهابل ثانيا: المراجع أ- المراجع العربية والمعربة - احمد بري، ممدوح غالب تاريخ التصوف في الدولة العثمانية، الطريقة البكتاشية نموذجا( برلين: المركز الديمقراطي العربي للدراسات الاستراتيجية والسياسية والاقتصادية، د. ت)

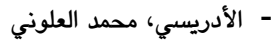
نصوص من التراث الصوفي (د. م: دار الثقافة، 2008م) محدم) أرمان، محمد التاي كيمن، تركيا دولة سيكلوكلو( كونيا: معهد الدراسات التركية، 2001م) مدمدي - الأفغاني، عناية الله ابلاغ

جلال الدين الرومي بين الصوفية وعلماء الكلام ( الدار المصرية اللبنانية: 1987

$$
\text { - الآملي، محسن الحسين }
$$$$
\text { أعيان الشيعة (د. م: دار التعارف، 1998، 192م) مج14. }
$$

- آملي، سيد حيدر

المقدمات من كتاب نص النصوص في شرح فصوص الحكم لمحي الدين ابن العربي (تصحيحات: هنرى كربين وعثمان اسماعيل يحيى (تهران: انستيتو ايران

$$
\text { وفرانسه بزوههشهاى علمى، } 1975 \text { م) جـ } 1
$$

- الياد، ميرسيا

تاريخ المعتقدات والأفكار الدينية، ترجمة: عبد الهادي عباس ( د. م: دار دمشق،

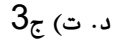

-

مولانا جلال الدين الرومي (إسطنبول: جامعة الفاتح، 2007م) جونان.

بابائي، حبيب الله

جدلية النظر والعمل في التأسيس الاسلامي لالهيات الحضارة، ترجمة: حسين صافي( بيروت: مركز الحضارة لتنمية الفكر الاسلامي واتجاهاته، 2014مي لاتهيات

- الباباني، اسماعيل باشا محمد أمين مير سليم مدية العارفين وأسماء المؤلفين وأثار المصنفين من كشف الظنون، اعتنى به محمد

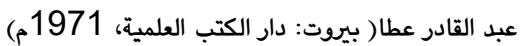

1911م) ص11" جعل ابن عربي "المرأة البتول" رمزا للحب الالهي ومزج بين الحب الالهي ، وحب المرأة فهوفي أشعاره يوميء الى الواردات الالهية والنزلات الروحانية أبن العربي، محي الدين بن علي، ترجمان الأشواق، اعتنى به: عبد الرحمان

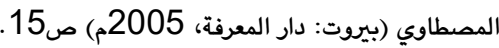
8- الحقيقة المحمدية: أوجده الله تعالى قبل كل شئ، من حضرة الغيب، ولا تعرف

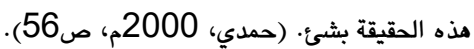
9- النور المحمدي: أي أن أرواح الأنبياء وأنوار الأنبياء قد فاضت من النور المحمدي الذي هو العقل الأول. (تاج الدين بن زكريا، د. ت، ص11) .

\section{7. قائمة المصادر والمراجع}

القرآن الكريم:

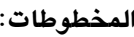

- تاج الدين بن زكريا، سلطان العثماني مخطوط ، أداب المريدين ورسائل صوفية أخرى، رقم1029 رحئ ( كتابخانه مجلس

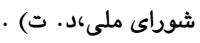

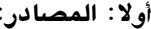

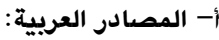

التادفي، محمد بن يحيى الحنبلي (ت 963هـ/ 1555م)

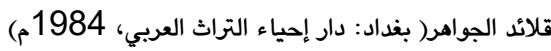

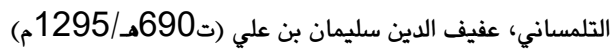
شرح فصوص الحكم للشيخ الأكبر ابن عربي، تحقيق وتقديم: أكبر راشدي نيا (بيروت: دار الكتب العلمية، 1971م)

بن تيمية، احمد بن عبد الحليم

فتاوى شيخ الاسلام( السعودية: مجمع الملك فهد لطباعة المصحف الشريف، . 2004 الذهبي، شمس الدين محمد بن أحمد بن عثمان (748هـ/1348م) سير أعلام النبلاء، تحقيق: بشار عواد معروف ومحي الدين هلال السرحان( د. م:

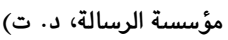

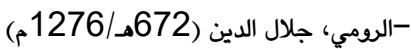
فيه ما فيه، ترجمة: عيسى علي العاكوب ( بيروت: دار الفكر المعاصر، د. م) ابن زروق، ابي العباس احمد بن احمد بن عيسى الفاسي البرنسي قواعد التصوف، تدقيق: عبد المجيد خيالي ( بيوت: دار الكتب العلمية، ط 2 ،

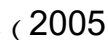
أبن عربي، محي الدين بن علي (ت638هـ/ ( الفتوحات المكية، تحقيق وتقديم: عثمان يحيى (د. م: الهيئة المصرية العامة للكتاب،

ترجمان الأشواق، اعتنى به: عبد الرحمان المصطاوي (بيوت: دار المعرفة، (2005

الغزالي، محمد بن محمد ابو حامد الطوسي(ت505هـ/111م)

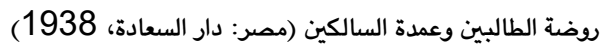

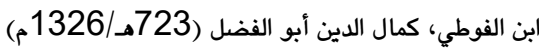
كتاب لمؤلف من القرن الثامن الهجري، المسمى وهما بالحوادث الجامعة والتجارب النافعة، تحقيق: بشار عواد معروف وعماد عبد السلام رؤوف ( د. م: دار

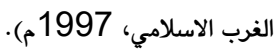

- الكفوي، الرومي محمود بن سليمان الحنفي (990هـ/1582م) ، كتائب أعلام الأخيارمن فقهاء مذهب النعمان المختار، أعتنى به : عبد اللطيف

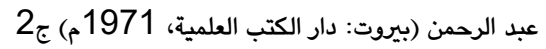

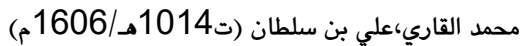


حسين ، أحلام عابد و فرست مرعي / مجلة العلوم الانسانية لجامعة زاخو، مجلد:9 ، العدد:3 ، ص 476- 491 ئيلون- 2021.

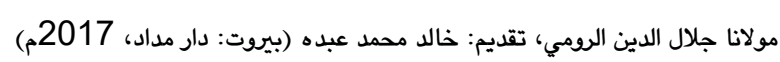

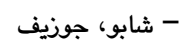

المتصوف جلال الدين الرومي ونتاجه الفكري( دمشق: منشورات الهيئة العامة

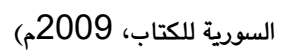

- شاه، ادريس

الصوفيون، ترجمة: بيومي قنديل، تقديم: هالة احمد فؤاد) القاهرة: دار الكتب

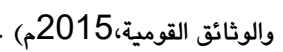
- عفيفي، أبو العلا التصوف الثورة الروحية في الاسلام (د. م: د. ت) . - عبدالله حسن، عبد اللطيف بن عبد الرحمن أثر العناصر الأجنبية في فكر بعض الشيعة الأثنى عشرية (الرياض: د. مبل مبن الرحن

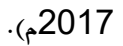

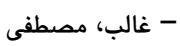
جلال الدين الرومي (بيروت: مؤسسة عز الدين، 1982م)

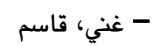

36- تاريخ التصوف في الإسلام، ترجمه عن الفارسية: صادق نشأت (القاهرة

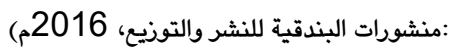
فتاح، عرفان عبد الحميد نشأة الفلسفة الصوفية وتطورها ( بيروت: دار الفكر، د. ت) فيد التميد - فروزانفر، بديع الزمان

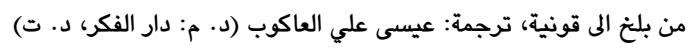

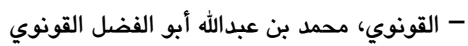

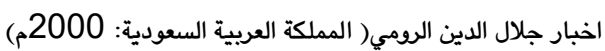

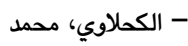
الفكر الصوفي في افريقية والغرب الاسلامي (بيروت: دار الطليعة، 2009م) محثد - كوبريلي، محمد فؤاد المتصوفة الاولون في الادب التركي، ترجمة: عبدالله أحمد ابراهيم(القاهرة:

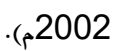
- المسيري، عباس

اليوجا والتصوف والرهبانية (القاهرة: مكتبة الأنجلو المصرية، 1983م) .

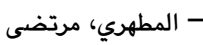

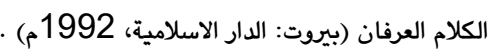
- مولوي، مراد

قصص مثنوي مولانا جلال الدين الرومي ( دمشق: الاوائل، 2010م) مراد

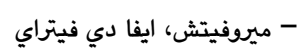
جلال الدين الرومي والتصوف، ترجمة: عيسى علي العاكوب (مؤسسة الطباعة

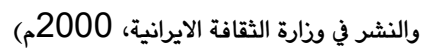

- نيكلسون، رينولد في التصوف الاسلامي وتاريخه، ترجمة: ابو العلا عفيفي ( القاهرة : 1969م) ب-المراجع الفارسية - آبادى، حسن اسماعيل نصر الفارسية برسى تحولات سياسي اجتماعي سلجوقيان روم، بايان نامه عى(دانشكاه

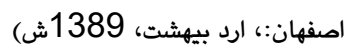

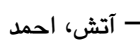
اثار فارسى در اناتولى، ترجمة: صائمة اينال صاوى( ايران: مرعشى قم، د: ت)

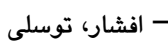

- بنعبد، عبدالله عبد العزيز

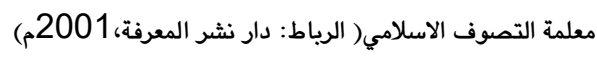

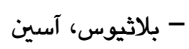
ابن عربي حياته ومذهبه، ترجمة: عبد الرحمن بدوي (القاهرة: مكتبة الأنجلو

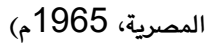

- ترمنجهام، سبنسر الفرق الصوفية في الاسلام، ترجمة: عبد القادر البحراوي ( دار المعرفة الجامعية،

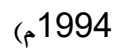

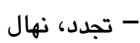

نار العشق، ترجمة: خالد الجبيلي ( بيروت: منشورات الجمل، 2015م) - تدين، عطاء الله بحثاً عن الشمس من قونية الى دمشق "جلال الدين الرومي وشيخه شمس تبريز" ترجئ

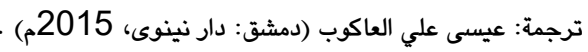

- حاج يوسف، محمد علي شمس المغرب "سيرة الشيخ الأكبر محيي الدين ابن العربي ومذهبه (حلب: فصلت

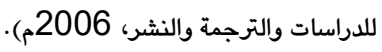
- حمدي، أيمن

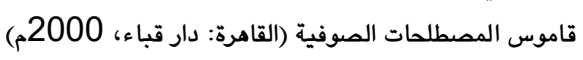

$$
\text { حسن، هاشم أبو الحسن علي }
$$

الله والإنسان عند جلال الدين الرومي (القاهرة: مكتبة الثقافة الدينية، د. ت) حسون، ندى الإنسان عند جن

الطب والمتعلقات به في مثنوي مولانا جلال الدين محمد مولوي الرومي( مجلة جامعة

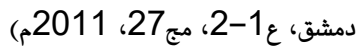

مناهج البحث في العلوم الأنسانية بين علماء الاسلام وفلاسفة الغرب (بيروت: دار

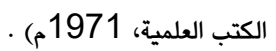

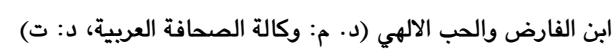
- رستم، سعد

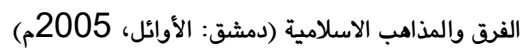

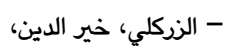
الاعلام، " قاموس تراجم أشهر رجال والنساء من العرب والمستعربين

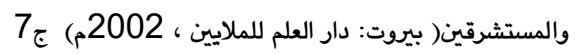
- زكي، حسن عباس مذاقات في عالم التصوف، تحقيق: خديجة النبراوي ( القاهرة : ط2، 2001 م)

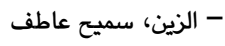
الصوفية في نظر الاسلام (بيروت: دار الكتاب اللبناني، القاهرة: دار الكتاب المصري، ط3، 1985 1985). - سلامة قدسي، عرين شوكت بين سير وطير" التنظير، حياة الجماعة، وينى المؤسسة في تصوف أبي حفص عمر قدري

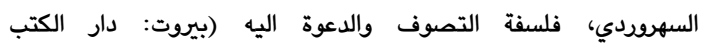

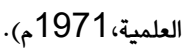

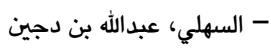
الطرق الصوفية نشأتها وعقائدما وآثارها (الرياض: داضن دار كنوز، 2005م) .

- مرف، محمد جلال دراسات في التصوف الاسلامي (الأسكندرية: دار المعرفة الجامعية، 1991م). - شيمل، آنا ماري الأبعاد الصوفية في الاسلام وتاريخ التصوف، ، ترجمة: محمد اسماعيل السيد رضا ( بغداد: منشورات الجمل، 2006م الاسلام وتاريخ التوف، ، مادم 
حسين ، أحلام عابد و فرست مرعي / مجلة العلوم الانسانية لجامعة زاخو، مجلد:9 ، العدد:3 ، ص 476- 491 ئيلون- 2021.

تاريخ نظم ونثر در ايران ودر زبان فارسى (تهران: انتشارات فروغي، 1344ش)

روند زهد وتصوف وعرفان در كستره ى اسلامى ايران (تهران: انتشارت دانشنامه،

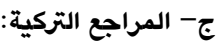

FÜRÜZANFER,

MEvLANA CELEDDİN, İstanbuL, 1963.

karapİnar, Fikret

mevLananİn EseLerİnde, Hadİs kÜLtÜrÜ, Marİfe, konea, 2015.

muammer Gul

mogul hakımıyeyı, istanbul ,2005.

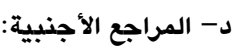

- MOhammed,Rustom

is ibnal-Arabi'sontolohy pantheistic,journal,of Islamic philosophy, (w.p,w,d)

Talbot Rice, Tamara,

THE SELjUKS IN ASIA MINOR( London: w, d)

ثالثً: الموسوعات والدوريات الفارسية، والمعربة: - آبادى، حسين خندق

دائرة معارف تشيع، (تهران، مؤسسة انتشارات حكمت، 1394ش، بادي، بات مولوي) جلد بانزدهم دانشنامه ادب فارسى ( تهران:1383 شانزم) سورديل، ·ح.ود. معجم التاريخ الاسلامي، ترجمة: الـ الحكيم فيرغسون، جون

الموسوعة الصوفية والديانات السرية، ترجمة: محمد الجورا( دمشق: دار الفرقد، 2014م)

رابعاً: البحوث الجامعية: الربيدي، فاطمة يحيى زكريا

سلطنة سلاجقة الروم في الأناضول منذ الغزو المغولي وحتى سقوطها( اطروحة دكتوراه: 2004 م) ص290.

-

الإثارة والعبارة وأثرها في ت تحديد المصطلحات الصوفية، مجلة FENOMENA,Vol.19.2020.
(ت. د.

- بايرام، ميكاييل

اوحد الدين كرمانى وحركت اوحدية، ترجمه ى: منصورة حسيني وداود وفايى(379

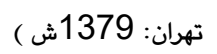
- بخش، جواد نور مردان صوفى ( تهران: 1379 ش) جوري - جيمه، محمد اختر

مقام شيخ فخر الدين ابراهيم عراقى در تصوف اسلامى (اسلام اباد: باكستان،

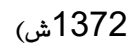

- ملبى، على اصغر عرفان واحوال عارفان، (تهران: انتشارات اساطير، 1377ش)

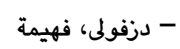
بيدايش طريقت علوى-بكتاشى در آناتولى، ( تهران: انتشارات علمى وفرهنكى،

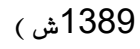
- زركوب، عبد الحسين آرزش ميراث صوفية، ( تهران: انتشارات آريا،1333شيد الشين - رازنهان، محمد حسن 10- تاريخ وعقايد بكتاشية ( تهران: دانشكاه تربيت معلم، 2004م ) - - رياني، زهرا فرهنك ايرانى در قلمرو سلجوقيان روم) تهران: انتشارات علمى

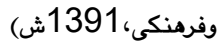

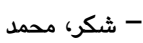
سلجوقيان شكست بيزانس در ملاذكرد وكسترش اسلام در اناتولي،مترجمان: نصر

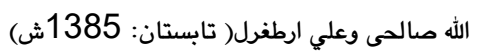

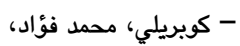
صوفيان نخستين در ادبيات ترك، ترجمة: توفيق سبحاني ( تهران: 1385 شواد) - مقدم، عليرضا تشكيلات آخيان وسير تاريخى آن ( دانشكاه شهيد بهيشتي: 1388ش)

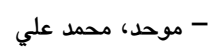

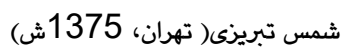
- نفيسي، سعيد تبريزيان تهران 


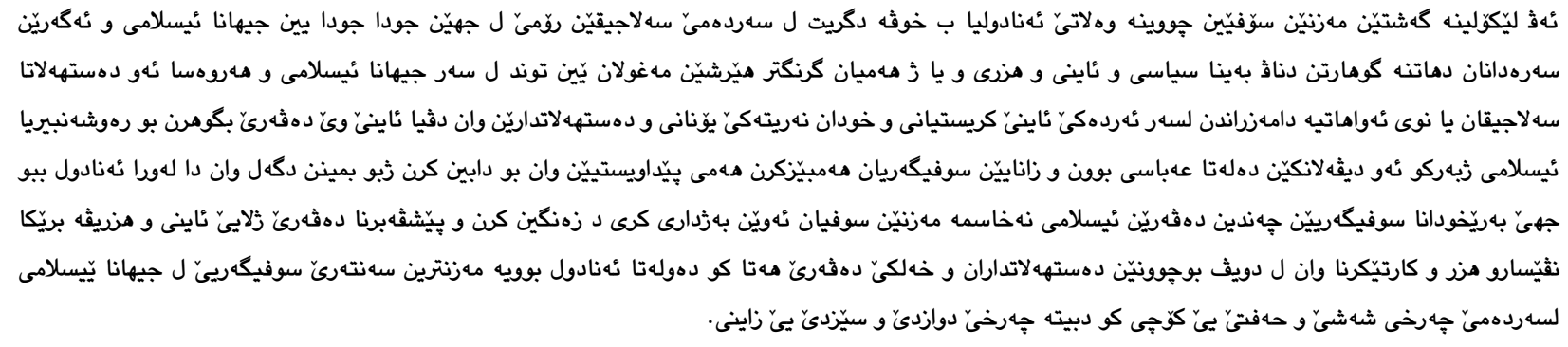

\section{Abstruct:}

Sufi journeys to Anatolia during the Seljuk period of Rum 704-600) AH/1200-1307 AD

This research deals with the study of the journeys of the great Sufis who came to Anatolia during the reign of the Roman Seljuks from various regions of the Islamic world. On a land of Christian religion and of a Greek character ; Its rulers were obliged to turn it into an area with an Islamic culture, as they were followers of the Abbasid Caliphate, so they embraced scholars and men of Sufism by providing what secures their survival. Anatolia became the destination of Sufism from many regions, especially senior Sufis and others, who contributed to enriching the region religiously and intellectually through their writings and ideas and their effective influence on limit the viewpoint of rulers and inhabitants; Until Anatolia became the largest center of mysticism in the Islamic world during the sixth and seventh centuries $\mathrm{AH} /$ the second and thirteenth centuries $\mathrm{AD}$.

Keywords: 